\title{
Gender-role development in toddlers: The association between parental gender-role orientation and toddler's gender-typed behavior
}

Jennifer K. Hartley

West Virginia University

Follow this and additional works at: https://researchrepository.wvu.edu/etd

\section{Recommended Citation}

Hartley, Jennifer K., "Gender-role development in toddlers: The association between parental gender-role orientation and toddler's gender-typed behavior" (2006). Graduate Theses, Dissertations, and Problem Reports. 2465.

https://researchrepository.wvu.edu/etd/2465

This Thesis is protected by copyright and/or related rights. It has been brought to you by the The Research Repository @ WVU with permission from the rights-holder(s). You are free to use this Thesis in any way that is permitted by the copyright and related rights legislation that applies to your use. For other uses you must obtain permission from the rights-holder(s) directly, unless additional rights are indicated by a Creative Commons license in the record and/ or on the work itself. This Thesis has been accepted for inclusion in WVU Graduate Theses, Dissertations, and Problem Reports collection by an authorized administrator of The Research Repository @ WVU. For more information, please contact researchrepository@mail.wvu.edu. 
Gender-Role Development in Toddlers:

The Association between Parental Gender-Role Orientation and

Toddler's Gender-Typed Behavior

Jennifer K. Hartley

Thesis submitted to the

Eberly College of Arts and Sciences

in partial fulfillment of the requirements

for the degree of

Master of Science

In

Psychology

Katherine Karraker, Ph.D., Chair

Kevin T. Larkin, Ph.D.

JoNell Strough, Ph.D.

Department of Psychology

West Virginia University

Morgantown, West Virginia

2006

Keywords: Gender, Gender-Role Development, Gender-Role Orientation, Toys

Copyright 2006 Jennifer K Hartley 


\author{
Abstract \\ Gender-Role Development in Toddlers: \\ The Association between Parental Gender-Role Orientation and \\ Toddler's Gender-Typed Behavior \\ Jennifer K. Hartley
}

Associations between the gender-role orientation of parents and the toy-play behavior of first-born infants were investigated. Fifteen fathers $(M$ age $=31.13, S D=4.26)$ and 46 mothers $(M$ age $=28.13, S D=4.97)$ completed self-administered questionnaires which included questions on feedback to play with gender-typed toys. ANOVA results indicated that mothers provided more masculine-typed toys for their sons than their daughters, and more feminine-typed toys for their daughters than their sons; fathers provided more feminine-typed toys for their daughters than their sons. In addition, mothers provided more encouragement to same-gender-typed play than cross-gendertyped play for both masculine- and feminine-typed toys, while fathers provided more encouragement to their daughters playing with feminine-typed toys than their sons. Results are discussed in terms of the gender-role socialization processes in which parents of young children engage, and the possibility of bidirectional socialization processes. 


\section{Dedication}

I would like to dedicate this thesis to Bryon Powell, who was the source of an endless amount of support. He stood by me through all the stress, all the ups and downs, and gave me the encouragement I needed every time I was ready to give up. Without his love, support, encouragement, and endless patience with my stress, this thesis would never have been finished. 


\section{Acknowledgements}

I would first like to thank Dr. Katherine Karraker, my advisor and chair of my committee, for all of her support in helping my complete my thesis. Her guidance and endless patience were key in my completing this project. I would also like to thank Dr. Cynthia Anderson, Dr. Kevin Larkin, and Dr. JoNell Strough for serving on my thesis committee. Their suggestions and clarifications helped this research a great deal. Finally, I would like to thank Loriann Sonntag and Jennifer Flinn for their help with various statistical procedures and the utilization of SPSS, as well as their unending support as friends. Without the contributions of each of these individuals, this thesis would not have been completed. 


\section{Table of Contents}

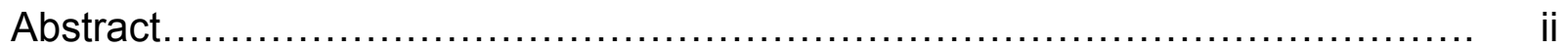

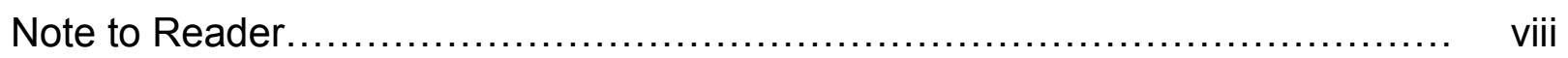

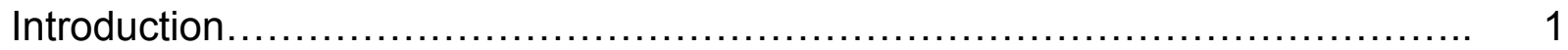

Gender Stereotypes..................................................... 2

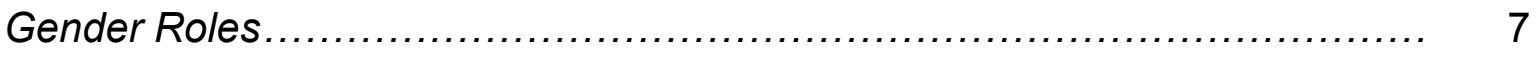

Gender-Role Orientation ................................................... 8

Gender-Role Socialization ............................................... 11

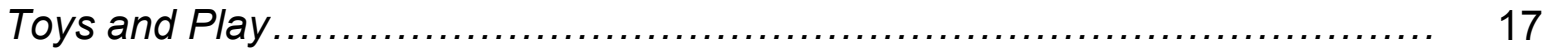

Statement of Purpose .......................................................... 23

Research Questions and Hypotheses........................................ 24

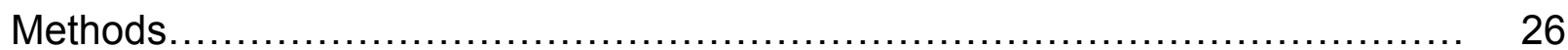

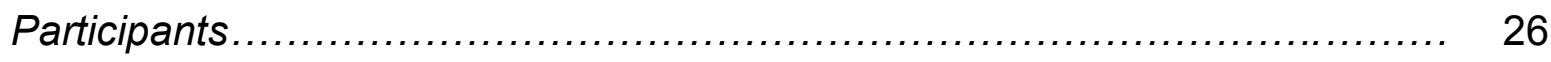

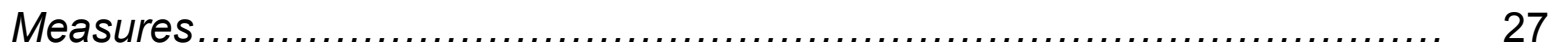

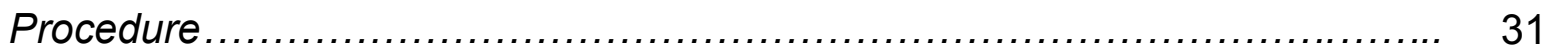

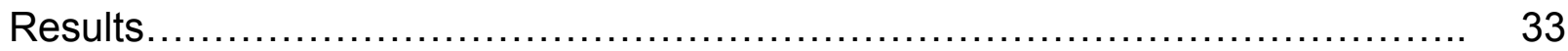

Sample Characteristics..................................................... 33

Preliminary Analyses.................................................. 33

Analyses of Hypothesis One ............................................ 34

Analysis of Hypothesis Two ............................................ 36

Analyses of Hypothesis Three ............................................ 37

Exploratory Analyses.................................................... 38

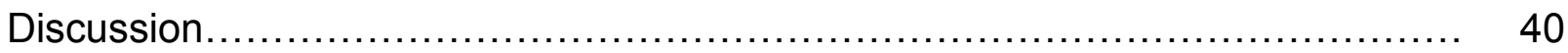


Recently Provided Gender-Typed Toys for Children .......................... 40

Likelihood of Providing Gender-Typed Toys in the Future...................... 42

Feedback Provided for Children for Play with Gender-Typed Toys.............. 43

Exploratory Analyses....................................................... 44

Limitations of the Study and Future Directions ............................... 46

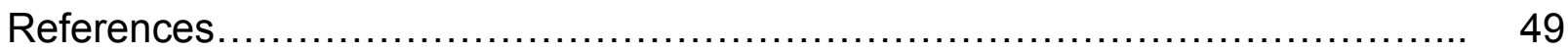

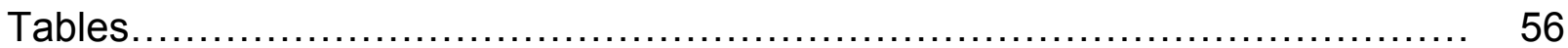

Table 1: Participant Demographics.......................................... 56

Table 2: Frequencies of Parent Gender-Role Orientations...................... 58

Table 3: Partial Correlations for Dependent Variables of Married Mothers and 59 Fathers.

Table 4: Partial Correlations for Dependent Variables of Fathers................ 60

Table 5: Partial Correlations for Dependent Variables of Mothers.............. 61

Table 6: Frequencies of Toys Recently Provided by Parents................... 72

Table 7: Analyses of Variance for Hypothesis One ............................. 73

Table 8: Means and SD: Toys Provided Divided by Child Sex.................. 74

Table 9: Means and SD: Toys Provided Divided by Gender-Role Orientation... 75

Table 10: Analyses of Variance for Hypothesis Two ........................... 76

Table 11 Means and SD: Likelihood of Providing Toys Divided by Child Sex.. 77

Table 12: Analyses of Variance for Hypothesis Three.......................... 78

Table 13: Means and SD: Feedback to Gender-Typed Play by Child Sex..... 79

Table 14: Partial Correlations of Temperament and Dependent and

Demographic Variables. 
Table 15: Intercorrelations of the Toddler Temperament Subscales............. 81

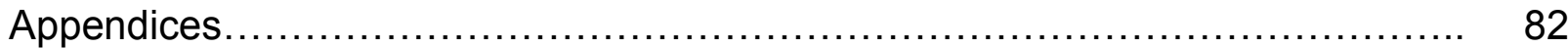

Appendix A: Recruitment Letter......................................... 82

Appendix B: Consent and Information Form ............................... 83

Appendix C: Packet Cover Letter........................................ 85

Appendix D: Flyer...................................................... 86

Appendix E: Telephone Text............................................ 87

Appendix F: Toy/Play Questionnaire....................................... 88

Appendix G: Bem Sex Role Inventory ..................................... 94

Appendix H: Demographics Questionnaire ................................ 95 
Note to the Reader

Throughout the literature, the terms 'gender' and 'sex' are used somewhat interchangeably, and there does not seem to be a clear distinction in the meanings of the two words. Although the literature is somewhat inconsistent, for the purpose of this paper, 'sex' will be used for biological distinction between males and females and 'gender' will be used for the social and cultural distinctions. 
Gender-Role Development in Toddlers: The Association between Parental Gender-Role Orientation and Toddler's Gender-Typed Behavior

Interest in gender differences has increased over the last few decades, and although gender differences have only been found in a limited number of areas (Maccoby \& Jacklin, 1974), researchers continue to analyze for gender differences in studies. Consistent differences have been found in play, both with the toys boys and girls use and the activities in which they engage during play. While numerous studies have illustrated that there are differences in play activities (e.g., Campenni, 1999; Lindsey \& Mize, 2001; Martin, Eisenbud, \& Rose, 1995; Martin \& Little, 1990; Raag, 1999; Raag \& Rackliff, 1998; Wood, Desmarais, \& Gagula, 2002), very little research has been done on what actually leads to these gender differences. Some research has begun investigating the influence of a person's gender-role orientation on his or her behavior, and some research has shown that gender-role orientation is a better predictor of behavior than sex (e.g., Karniol, Grosz, \& Schorr, 2003; Reeder, 2003). Recently, Eccles, Frome, Yoon, Freedman-Doan, and Jacobs (2000) suggested that the gender differences seen in play, in particular with the toys that boys and girls play with, may influence the gender differences seen in children's math and language skills. If this is the case, then it is important to understand what influences the initial segregation of girls and boys, and their play behaviors, which could then further the understanding of the gender differences seen in other areas.

This study investigated the influence of a parent's gender-role orientation on a child's gender-typed toy play by answering the following questions. Is there a relation between a parent's gender-role orientation and the gender-typing of the toys he or she 
provides for the child? Does a parent's gender-role orientation predict whether or not a parent will encourage or discourage his or her child's play with same- and cross-gendertyped toys?

\section{Gender Stereotypes}

Social psychologists have studied many different aspects of how the social world affects a person's thoughts and behaviors. Included among these aspects are stereotypes, which are defined as the schemas and characteristics that one assumes all members of a given group possess (Cleveland, Stockdale, \& Murphy, 2000). These stereotypes can be organized around any type of group division, such as religion, race, or gender, and the perceptions that a person has of another individual are influenced by what that person knows about the group as a whole (Cleveland et al., 2000). Gender stereotypes, in particular, consist of socially constructed beliefs regarding particular characteristics and attributes of men and women. These gender stereotypes, in turn, influence an individual's perception of a singular man or woman (Bauer \& Baltes, 2002). People use these societal stereotypes to help organize various aspects of the world, from academic success (e.g., boys are better at math and girls are better at English; Eccles et al., 2000) to colors (e.g., pink is for girls and blue is for boys; Picariello, Greenberg, \& Pillemar, 1990).

When meeting someone for the first time, one of the first things a person might notice is whether that person is male or female (Beal, 1994), which is a result of the nature of gender being "universal, dichotomous, and easily visible" (Barberá, 2003, p. 176). Research has found that one of the most important categories a person uses to 
arrange internal and external information is gender (Bem, 1981; Leinbach \& Fagot, 1986).

Even with newborns, the first question often asked is about the sex of the new baby. Intons-Peterson and Reddel (1984) conducted a study of first-time parents. The parents recorded questions that were asked when they contacted friends and family members to announce the birth of the baby. Of those questions asked, $80 \%$ were regarding the sex of the baby, with most of the questions worded such that there was an apparent preference for males (i.e., asking "Is it a boy?" or "Is it a boy or girl?" as opposed to "Is it a girl?" or "Is it a girl or a boy?").

The identification of another person's sex then activates the stereotypes and expectations held regarding the two sexes. Along with these expectations is the tendency to evaluate behaviors of the other person based on those expectations, which may lead not only to a biased interpretation of the actual behavior, but an interpretation that confirms the original expectation (Darley \& Fazio, 1980). This activation of expectations, therefore, may affect the behaviors a person will exhibit and the reactions the person will have to behaviors exhibited by others. According to Darley and Fazio, the pattern of interaction will continue in such a way that the target individual's behavior will begin to change to confirm the expectations of the perceiving individual, as later confirmed by Fagot, Hagan, Leinbach, and Kronsberg (1985).

Today, the sex of a child can be identified by the 12th week of pregnancy, although some parents elect not to have the doctor tell them and thus do not know the sex of the child until birth. Either way, as soon as the sex is determined and noted, gender stereotypes and expectations are activated. For example, Rubin, Provenzano, 
and Luria (1974) found that new parents often used gender-stereotypic descriptions when talking about their newborns. Despite the lack of any difference in birth weight, length, or APGAR scores, the parents were more likely to rate sons as firmer, largerfeatured, bigger, and more alert than daughters. While this difference in ratings was apparent for both mothers and fathers, the fathers tended to be more extreme in their ratings of both sons and daughters. Karraker, Vogel, and Lake (1995), in a follow-up of this study, found no evidence of fathers being more extreme in their ratings than mothers, perhaps due to the larger amount of time the fathers in their study had spent with their newborns prior to the interview. The fathers in the Karraker et al. study had spent an average of 13 hours with their newborns, whereas the fathers in the Rubin et al. study had spent an average of 1 hour with their newborns. As a result, the fathers in the Karraker et al. study may have been less likely to rely on stereotypes usually associated with girls and boys, and more likely to rely on their actual experiences with their children. Karraker et al. also found that, while parents continued to have some gender-stereotypic perceptions of their newborns, they no longer had as many as found by Rubin et al. Further, Stern and Karraker (1989), in a review of the gender label manipulation literature, found that the descriptions of infants given by adults were not likely to have been affected by gender stereotypes based on the labeled sex of the infant. Rather, the behaviors exhibited by the adults were much more likely to be influenced, such that adults seemed to steer infants toward activities that are stereotypically appropriate for each gender. As a result, it is possible that, while young infants do not spontaneously exhibit gender-typed behaviors, the adults who interact with them steer the infants in the direction of stereotypic behavior through the adults' 
own behaviors and the reactions the adults have to the behaviors of the infants. The behaviors and reactions of the adults are, in turn, being influenced by the stereotypes the adults hold. Thus, the self-fulfilling prophecy occurs.

When parents treat their sons and daughters differently, they do so in a manner that is consistent with their expectations of how their sons and daughters should behave (Eccles et al., 2000). As a result of the differential treatment by their parents, the children then begin to behave in ways that are consistent with their parents' expectations, as seen in the self-fulfilling prophecy (Darley \& Fazio, 1980). This activation of stereotypes can also be seen through the behaviors that parents and others exhibit, whether it includes painting the nursery blue for a boy or pink for a girl, or providing little girls with dresses and ruffles and boys with jeans and shirts with sports logos (Fagot, Rodgers, \& Leinbach, 2000). For example, in a study of adults' perceptions of infants when the true sex was unknown, adults were asked to describe the reaction of 9-month-old infants who had been surprised by a Jack-in-the-box toy. The adults who had been told that the infants were boys described the infants' reactions as anger, whereas the adults who had been told the infants were girls described the reactions as fear (Condry \& Condry, 1976), indicating that in situations where there is little interaction and experience with the infant, adults tend to rely on gender stereotypes in interpreting behaviors, which could then lead to differences in the adults' responses to infants and thereby activating the self-fulfilling prophecy.

In another study concerning how adult behaviors steer infants into genderstereotypic behaviors, Leeb and Rejskind (2004) looked longitudinally at mutual gaze, a behavior that is a key component of adult social interactions, with neonates and infants. 
Leeb and Rejskind observed newborns between the ages of 13 and 112.25 hours engaging in mutual gaze behavior with unfamiliar adults, with a follow-up observation occurring approximately 4 months later. The adults who were attempting to engage the infants in mutual gaze behavior were blind to the sex of the infant, so as to decrease the likelihood of bias entering into the interaction. While there were no significant differences in the amount of eye contact for boys and girls at the first time of measurement, there was a significant difference at the time of follow up, with girls having more eye contact than boys. In fact, the mean time for boys did not change from time 1 to time 2 , whereas the girls showed a mean increase of $480 \%$. The researchers suggested that, given that there were no differences between the boys and girls in the gazing behavior at time 1 , it is unlikely that the difference seen at time 2 is a result of innate processes. According to Leeb and Rejskind, this difference indicates that, even at a few months of age, gender-type socialization, where girls are being socialized toward being more social while boys are being socialized toward being more independent, may already be occurring for some behaviors. Whether or not this study accurately illustrates the gender-role socialization process is unclear, however, since it is possible for an innate behavior or process not to manifest immediately at birth, and instead appear later.

If this gender-type socialization is already occurring, then it seems reasonable to attempt to ascertain what is contributing to the socialization process. How do the stereotypes a parent has regarding the differences in males and females influence his or her socialization of the infant? Does the parent's gender-role orientation, the level of self-subscription to those stereotypes, influence the socialization of the infant? 


\section{Gender Roles}

According to Beal (1994), the stereotypes that people hold help people construct their own concept of being male or female. These stereotypes delineate the gender roles available, defined as the expectations that society holds regarding the behaviors and attitudes that are appropriate for each gender. While the distinction between gender stereotypes and gender roles is small, gender stereotypes typically refer to a person's cognitive beliefs about males and females while gender roles typically refer to the expectations about being male or female (Helgeson, 2004).The individual can then adopt some or all aspects of the societal male or female gender role into his or her personal gender role (Holt \& Ellis, 1998). Gender stereotypes are often characterized by placing males and females on the opposite ends of the same spectrum, such that a person can be either masculine or feminine, but not both. However, research has shown that masculinity and femininity actually consist of two different scales, such that one person can possess masculine and feminine qualities simultaneously (Bem, 1974; 1977). Rather than being either masculine (i.e., high on the masculine scale and low on the feminine scale) or feminine (i.e., high on the feminine scale and low on the masculine scale), a person could also be androgynous, defined as possessing a high number of both masculine and feminine characteristics, or undifferentiated, defined as having a low number of masculine and feminine characteristics (Bem, 1974). Regardless of how a particular individual is oriented on the scales of masculinity and femininity, each individual has knowledge of gender stereotypes and gender roles. Furthermore, as a person's gender-role orientation involves the internalization of some 
of the stereotypes for himself or herself, the stereotypes and gender roles associated with each gender must be learned somehow.

In addition to constructing their own gender concept, people make use of gender stereotypes as a way of maintaining their own sense of gender identity. Spence (1993) found that men and women have a tendency to identify the characteristics they possess that are in agreement with gender stereotypes as a way of confirming to themselves their own gender identities while disregarding the fact that they also possess characteristics conventionally considered to be associated with, or attributed to, the opposite sex. Also noted was the fact that, even among individuals who identify very strongly with a particular gender, "men and women do not exhibit all of the attributes, interests, attitudes, roles, and behaviors expected of their sex" (p. 633) based on gender stereotypes. Despite this discrepancy, Spence noted that men and women both tended to dismiss the significance of the gender-consistent characteristics that they did not have, still considering themselves to be either masculine or feminine, respectively. When looking at gender-role orientation, this tendency is important to consider because feminine mothers and masculine fathers might be more likely to endorse their feminine and masculine characteristics, respectively, than mothers and fathers with the other gender-role orientations.

\section{Gender-Role Orientation}

As an individual is socialized according to gender roles, he or she comes to develop a gender-role orientation. Although referred to as "sex-role orientation" in the literature, the term "gender-role orientation" will be used to remain consistent with the previously discussed distinction between "sex" and "gender." Bem (1974) described four 
different orientations based on an individual's scores on a scale of masculinity and a scale of femininity. An individual with a low score on both scales would be considered undifferentiated, high femininity and low masculinity indicates a feminine gender-role orientation, high masculinity and low femininity indicates a masculine gender role, and high scores on both scales indicates an androgynous gender role. For the purpose of this study, women with a feminine gender-role orientation and men with a masculine gender-role orientation are designated as having a traditional gender-role orientation, while women with a masculine, androgynous, or undifferentiated gender-role orientation and men with a feminine, androgynous, or undifferentiated gender-role orientation are designated as having a nontraditional gender-role orientation.

According to Bem $(1974 ; 1977)$, an androgynous gender-role orientation is considered to be ideal, as it allows for the individual to adapt effectively in all situations by utilizing characteristics that are traditionally associated with women and those characteristics traditionally associated with men. A man with a masculine gender-role orientation or a woman with a feminine gender-role orientation, on the other hand, will tend to exhibit only behaviors associated with his or her gender and not exhibit crossgender behaviors (Bem). Some research has confirmed Bem's beliefs about the benefits of androgyny. For example, Pyke (1985) found that androgynous participants were more flexible or more adaptable than participants with the other three gender-role orientations. In addition, Pyke found that androgynous participants showed greater psychological adjustment than undifferentiated or feminine participants; the adjustment of masculine participants did not differ from androgynous participants. Similarly, Heilbron and Han (1986) found that androgynous women were more adaptable and less 
stressed than non-androgynous women, although there was no corresponding relation for men.

More recently, Shimonaka, Nakazato, Kawaai, and Sato (1997), found that throughout the lifespan there was a relation between androgyny and successful adaptation, and Cheng (2005) found that while androgynous individuals do not necessarily know more about coping than individuals with other gender-role orientations, androgynous individuals were less depressed than other individuals and were more aware of situational characteristics and utilizing various strategies that fit changing situational characteristics than were individuals with other gender-role orientations. Thus, some support for the benefits of androgyny is available, although some theorists argue that, rather than an androgynous gender-role orientation being linked with positive psychological adjustment, an individual's score on the masculinity scale is more indicative of positive psychological adjustment (Adams, 1982; \& Kimlicka, Sheppard, \& Wakefield, 1987). With respect to psychological adjustment, results for women show that androgynous and masculine women are better adjusted than feminine women. Despite the apparently clear-cut evidence for women, the evidence for the relation between psychological adjustment and gender-role orientation for men is still mixed (Bowers, 1999; Shimonaka, Nakazato, Kawaai, \& Sato, 1997).

A person's gender-role orientation can be easily identified using a measure like the Bem Sex Role Inventory (BSRI), yet how does one develop a particular gender-role orientation? What, or who, influences a child's development of a gender-role orientation? Does the parent's gender-role orientation influence the gender-role socialization process of children? 


\section{Gender-Role Socialization}

Depending upon the age and environment of the child, different people (e.g., parents, siblings, peers, and teachers) may act as the socializing agents through which gender information is passed to the child. For example, Fagot et al. (1985), in a study of infants, found that there were no sex differences in communication attempts with adults or assertive acts at $13-14$ months of age. However, analysis of the children's teachers' reactions showed that the teachers responded more to acts of assertion from boys and attempts to communicate by girls. When the researchers followed up 11 months later, there were sex differences in the children's behavior, such that the boys were more assertive than the girls and the girls showed more attempts at communication than the boys. At this time, there was also no longer any differentiation in the reaction of the teachers to the behaviors of the children. Because the infants showed no difference in their behaviors at 13 months, the findings suggest that the teachers relied on the stereotypes that they held regarding the behavior of boys and girls. Thus, because stereotypes tell us that boys are more assertive than girls and girls are more verbally communicative than boys, the teachers may have attended differently to these behaviors for boys and girls. As a result, the infants' behavior was shaped into the expected stereotypical behavior (Fagot, et al., 1985).

For the most part, the primary socializing agents for infants and toddlers are parents. Fagot and Leinbach (1989) conducted a study to see if the reactions of parents to a child's gender-typed behavior would accelerate the child's understanding of gender. The results indicated that the children who were successful in a gender-labeling task, in which children were presented with pairs of pictures of either children or adults and 
were asked to identify, by either pointing or touching, the picture that corresponded to the label of 'boy' or 'girl,' at an earlier age had parents who provided more attention to the child when he or she played with gender-typed toys. Fagot and Leinbach noted that the main effect of the parent providing more attention occurred regardless of the type of attention received, the gender-typing of the toys played with by the child, and whether the child was male or female. Thus, these results indicate that it is not so much what the parents are saying about gender information as the affective responses that parents provide while the children are playing that influences how early children are able to pass a gender-labeling task.

The socialization process involves not only the shaping of specific gender-typed behaviors, but also the transmission of attitudes from the socializing agent (e.g., the parent) to the individual (e.g., the child; Moen, Erickson, \& Dempster-McClair, 1997). Moen et al. found that when the attitude transmission is effective, it occurs more through verbal influence than role modeling, as there was no relation between the amount of engagement the mothers had in the work force during their daughters' childhood and adolescence and the gender role attitudes the daughters held as adults. Thus, it was what the mothers said, rather than what they did, that accounted for the transmission of gender role attitudes from mother to daughter.

Ex and Janssens (1998) looked specifically at the socialization of daughters by mothers and found that mothers with more traditional gender-role attitudes tended to place more emphasis on gender conformity with their daughters as children than did mothers with less traditional gender-role attitudes. Upon follow-up measurement, when the children were adults, these daughters held more traditional attitudes than the 
daughters of less traditional mothers, although the attitudes of the daughters overall were not as traditional as the attitudes of their mothers. Further, mothers who were more educated held less traditional gender-role attitudes, which were then reflected in their daughters' attitudes (Ex \& Janssens, 1998). Thus, if the gender-role attitudes of the child are associated with the gender-role attitudes of the mother, it seems reasonable to question whether or not the gender-role orientation of the mother is also associated with the gender-typed play of the child.

In addition to verbal influence and the emphasis of gender conformity, gender role attitudes can also be transmitted from parents to children via behaviors. McHale, Bartko, Crouter, and Perry-Jenkins (1990) looked at the relation between the genderrole orientation of parents and the household tasks children are involved in. The researchers found that, when looking only at the chores the children were performing, girls spent more time performing feminine tasks (e.g., making beds and food preparation) than boys did. When the researchers considered the gender-role orientations of the parents, fathers in single-earner families were more traditional than were fathers in dual-earner families. This difference in traditionality in the gender-role orientations of fathers also translated into the chores that the children performed, such that sons in single-earner families performed significantly fewer feminine chores and significantly more masculine chores than did daughters of single-earner families, whereas the division of chores in dual-earner families showed less division along gender lines.

Although some research has suggested that fathers do not seem to have more influence in the socialization of children than mothers, and that mothers and fathers 
appear to be equally involved in the socialization process (e.g., Roopnarine, 1986; Lytton \& Romney, 1991), other research has shown that fathers may be more differential in their treatment of their daughters and sons than mothers, and thus more influential in the socialization process (Maccoby, 1998). Fagot and Hagan (1991) have suggested that during the second year of life, children are learning new skills at the same time that parents are still trying out different parenting styles, so the parents may rely more on gender stereotypes and use stereotypical responses more in situations where they are unsure of themselves. As a result, the parent's gender-role orientation may act as a mediator between the stereotypes the parent holds and the socialization behaviors the parent exhibits, and thus play a larger role in gender-role socialization during this period of an individual's development when compared to other periods. This may also be the reason why fathers appear to be more differential. Since mothers typically spend more overall time playing with their children during the first two years of life than fathers (Hughes, 1999), mothers will be less likely than fathers to rely on gender stereotypes, although both mothers and fathers will be relying more on gender stereotypes with their first child than with later children.

Overall, the research considering parent gender-role orientation in conjunction with the play behavior of children is very limited. However, there has been research in other domains that has investigated the effect of a person's gender-role orientation on the behavior he or she exhibits. For example, Karniol, Grosz, and Schorr (2003) looked at relations among participants' gender-role orientation, sex, and ethical orientation (i.e., an ethic of care versus an ethic of justice). The researchers found that more of the variation in the ethical orientations a person adopted was accounted for by the person's 
gender-role orientation than the person's sex. Individuals with a feminine gender-role orientation had higher caring scores than did individuals with a masculine or androgynous gender-role orientation. Moreover, individuals with a higher caring score were more likely to volunteer than individuals with a lower caring score. While this translated into more females volunteering than males because females are more likely to have a feminine gender-role orientation than males, the gender-role orientation of the males who volunteered did not differ from the gender-role orientation of the females who volunteered.

Reeder (2003) also looked at a person's gender-role orientation, this time in relation to forming same- and cross-sex friendships. Reeder found that individuals with a nontraditional gender-role orientation (e.g., feminine men and masculine women) formed more cross-sex friendships than did individuals with a traditional gender-role orientation (i.e., feminine women and masculine men), whereas traditional individuals formed more same-sex friendships than did nontraditional individuals. Thus, it is apparent that a person's gender-role orientation can, in fact, influence his or her behavior. Research has also shown how the behavior of one person can influence the behavior of another person, so it is possible that a parent's gender-role orientation can, therefore, influence the behavior of a child, particularly the child's play behavior. For example, a mother with a feminine gender-role orientation may not approve of her daughter or son playing with masculine or feminine toys, respectively, and attempt to decrease that behavior, whereas a mother with an androgynous gender-role orientation would be more open to or tolerant of her child playing with toys typically considered appropriate for the other gender. 
In addition to outside socializing agents acting on the children, children may also act as socializing agents for their parents, introducing a reciprocal element into the gender-role socialization process. This reciprocal process can be seen in the way parents may change their behavior in response to reactions from their children. With respect to toy purchasing behavior, for example, a parent may purchase a variety of toys for his or her child, and then determine what types of toys to purchase in the future based on the toys with which the child plays. Parents may also select toys for their children based on their children's individual characteristics, such as temperament. Few studies have investigated whether or not the child's temperament has an influence on the child's toy and play behavior, or the toy purchasing behavior of parents, but some research has looked at the relation between temperament and parent behavior. Gordon (1981) found that child temperament, along with child sex, influenced the amount of controlling behavior exhibited by the mother. Nelson and Simmerer (1984) found that there was a relation between child temperament and paternal involvement, limit setting, and intimacy with the children, who were between 41 and 52 months of age. The same relations, however, were not found for mothers. More recently, Dixon and Smith (2003) found that temperament measurements taken at 13 and 20 months were predictive of the mother's behavior in play situations with their children, which seems to indicate that mothers may be adjusting some of their play behaviors to fit their children's temperamental characteristics. Thus, the question of whether or not parents are altering their toy purchasing behavior or feedback provided to their child's play behavior based on their child's temperament, or specific temperamental characteristics, still remains. 
Toys and Play

Much of the research with children that is designed to study differences in parents' treatment of children has involved play, and by extension play with toys, mainly because play is a particularly salient form of interaction for parents and their children (Leflamme, Pomerleau, \& Malcuit, 2002). Parents are, however, consistently providing information for the socialization process (Fagot et al., 2000). So, the question then becomes, how is gender socialization accomplished? What are parents actually doing that provides for this transmission of gender stereotypes, expectations, and roles? One way that this socialization can occur is through parents' play with their children. Past research has often studied parental treatment of sons and daughters to see if there are any differences in the treatment of the children related to the sex of the child or the parent (for a review, see Lytton \& Romney, 1991). Lytton and Romney concluded that there are very few differences in treatment of boys and girls by parents overall. However, one of the areas in which a difference was seen is play activity. Yet, while parents do seem to emphasize gender stereotypes in their children's play behavior, there is no evidence of fathers being more differential in their treatment of children than mothers.

Several studies have shown that gender-stereotypic behavior is already being consistently exhibited by children by the time they reach 3 years of age (e.g., Campenni, 1999; Lindsey \& Mize, 2001; Martin, Eisenbud, \& Rose, 1995; Martin \& Little, 1990; Raag, 1999; Raag \& Rackliff, 1998; Wood, Desmarais, \& Gagula, 2002), so the socialization process must begin before then. Martin and Little (1990) worked with children from 35 to 65 months of age and found that the children had to possess only a 
very basic awareness of gender for differential preferences to be exhibited with regard to toys and peers. The researchers found that it is not even necessary for the child to understand that gender is consistent, and does not change across situations, for gender information to influence the child's preferences for toys and peers. Rather, a child only needs to know with which group (boy or girl) he or she belongs for same-gender preferences for toys and peers to be exhibited (Martin \& Little). In an expansion of this idea, Martin et al. looked at how children without prior knowledge of the gender-typing of unfamiliar toys would make judgments regarding the appropriateness of the toys for other boys and girls. The results showed that, if the child remembered the gender label that had been assigned to the toy, then the child would base the appropriateness of the toy for boys and girls, and the amount the child and other children liked the toy, on that gender label. If the child did not remember the gender label assigned to the toy, then the child based his or her reasoning about whether or not other children would like the toy and the appropriateness of the toy for boys and girls on his or her own preference. In other words, if the child liked the toy, and the child was a boy, he reasoned that other boys would like the toy and girls would not, and that the toy was appropriate for boys but not for girls.

Another manner through which this socialization is seen is through the toys provided for children by adults. Many studies report that parents are more likely to purchase same-gender-typed toys for their children than cross-gender-typed toys (Kim, 2002; O’Brien \& Huston, 1985; Pomerleau, Bolduc, Malcuit, \& Cossette, 1990; Rheingold \& Cook, 1975; Zammuner, 1987). A study conducted by Rheingold and Cook looked specifically at similarities and differences in the toys found in the rooms of 96 
boys and girls from less than a year up to 6 years of age. Very little difference was found with regard to books, stuffed animals, musical objects, or furniture. However, more dolls were found in girls' rooms while boys' rooms had more toy zoos or barns with animals and objects associated with space, energy, or time (e.g., space ships, magnets, puzzles). There were some dolls in boys' rooms, but they were typically of the cowboy or GI Joe variety, rather than females or babies. The greatest difference seen, however, was in the number of vehicles in boys' rooms (375) when compared to girls' rooms (17). The authors also pointed out that only girls had doll houses, stoves, tea sets, and cradles for dolls, whereas only boys had live animals, depots, replicas of heavy equipment, and military toys. Rheingold and Cook mentioned that, as girls at 18 months of age spent as much time playing with trucks in the laboratory as boys did, it would seem that parents are steering the children in certain directions. Rather than attuning to the particular interests expressed through their young children's behavior, or providing the same types of toys for all children to discover possible interests, parents are providing entirely different arrays of toys for boys and girls to play with (Rheingold \& Cook).

To see if the differences identified 30 years ago by Rheingold and Cook (1975) still existed, Pomerleau et al. (1990) conducted a survey of infants' environments. A difference in toys was still found, with boys having more sports equipment, tools, and vehicles, both large and small. Girls had more dolls, children's furniture, and fictional toys. In addition to the toys, Pomerleau et al. found that the children's clothing also differed, such that girls wore pink and multi-colored clothing more often and boys wore red, blue, and white clothing. Boys also had more blue pacifiers while girls had more 
pink pacifiers (Pomerleau et al., 1990). This more recent survey indicates that boys and girls are still being exposed to different environments for socialization, and that these differences in the environment appear very early in life.

In a related study, Campenni (1999) asked parents and childless adults to rate 206 toys on a 9-point Likert-type scale ranging from "only appropriate for girls" to "equally appropriate for girls and boys" to "only appropriate for boys." Campenni found that there were differences between the parents and childless adults, such that the adults without children of their own were more extreme in their ratings of the genderappropriateness of toys than were parents. An interesting additional note was that Campenni had the participants rate the same list of toys for children under 2 years of age and found that a greater number of the toys were rated as gender-neutral rather than gender-typed. Overall, these findings suggest that parents may be more flexible in what is considered gender appropriate and gender inappropriate for infants than for older children, although new parents may be more stereotypical in their gender-typing of toys than parents who already have at least one child.

The socialization process also occurs in the toy-play sessions. For example, Wood et al. (2002) investigated the relation between an adult's parenting experience and their perceptions of the gender-stereotyping of children's toys. Each child interacted in play sessions with one of their own parents, one other parent, and one adult who was not a parent. Fifteen different toys were provided for each play session. After each play session, the adults then completed measures regarding the desirability and genderappropriateness of the toys. Wood et al. found that boys spent the majority of their time playing with toys rated by the participants as masculine, while girls spent the majority of 
their time playing with either feminine or gender-neutral toys. Moreover, this pattern was exhibited regardless of whether the adult playing with the child had any prior parenting experience.

In addition to children's toy choices, the type of play they initiate and in which they engage has been studied. Lindsey and Mize (2001), in a study of preschool children from 43 to 80 months of age, found that parent-daughter dyads engaged in more pretend play than did parent-son dyads, and that mother-child dyads engaged in more pretend play than did father-child dyads. Also, father-son dyads showed more physical play than did father-daughter dyads. With regard to the initiation of play in these situations, more assertive play behavior strategies were used with boys than with girls, and girls were exposed to more egalitarian and polite play initiations than were boys, particularly from fathers.

However, a parent does not always have to be physically present in the play situation to exert an influence on a child's play behavior. In a study of 4- and 5-year-old children, Raag and Rackliff (1998) examined children's awareness of expectations held by family and friends concerning cross- and same-gender-typed behavior. When the child was provided with gender-typed information regarding the tools and dishes available for play (i.e., that tools are toys that boys usually play with and dishes are toys that girls usually play with), as opposed to a condition in which the child was provided with no gender-typed information, boys who reported thinking that their fathers would consider cross-gender-typed behavior 'bad' played less with dishes and more with tools. This effect was seen even though only one of the boys said that he did not like the dishes when asked (Raag \& Rackliff, 1998). Raag (1999) followed this up by adding a 
third condition in which some children were provided with gender-typed information that was unrelated to the toys provided (i.e., information about children's clothes). Raag found that this third condition had little effect on girls, but that for boys who thought that one or more of their friends or family members considered cross-gender-typed behavior "bad," even the unrelated gender-typed information increased their preferential play with the tools (although not as much as did the related gender-typed information). Raag suggested that the different effect of gender-typed information on toy play for the boys and girls is a result of gender being more salient for boys than for girls, and that there may be fewer negative consequences for cross-gender-typed play for girls than for boys. As a result, boys may be more affected by gender-typed information, even when that information is not related to the task at hand, than are girls.

For children, toys and play are very salient aspects of the gender-role socialization process, and their preferences for same-gender-, cross-gender-, and gender-neutral-toys can be influenced by a variety of things, from simply providing gender-typed information to the child's perception that someone he or she knows would find cross-gender-typed play behavior "bad." As the preferences that the child develops may then influence the gender-role development, and the eventual gender-role orientation, of the child, it is important to try and identify the effects that feedback to play with gender-typed toys, real or imagined, may have on the child. While there has been evidence supporting the process of fathers discouraging play with cross-gender-typed toys, particularly for their sons (Maccoby, 1998), there has not been any research that investigated the amount of encouragement and discouragement that parents provide when their children play with gender-typed toys. 


\section{Statement of Purpose}

A great deal of research has identified gender differences in the play behaviors and toys of children, yet little is known about what, specifically, is contributing to the gender differences seen in the types of toys that children play with. For example, do parent attitudes and behaviors influence the gender differences seen in children? Why do parents provide different toys for their sons and daughters? If the suggestion made by Eccles et al. (2000) is correct, that it is in fact the toys that girls and boys are playing with that contributes to the later gender differences seen in math and verbal abilities, then it is important to understand who or what is influencing the gender socialization that children go through with respect to the gender-typing of toys and the use of those toys in play. Research has shown that the parent's gender-role orientation can influence the behavior they exhibit, which can in turn affect the behaviors exhibited by others. Due to the relatively large amounts of time parents spend playing with their children, as compared to other adults, it seems reasonable to ascertain whether or not the parent's gender-role orientation influences what type of toy the parent is providing for the child and whether or not the parent's gender-role orientation is influencing the reactions the parent would have to the child's toy choice. This influence of the parent's gender-role orientation on toy choice and play behavior may, in turn, influence the gender-role development of the child.

As research has shown strong gender differences in play and toy preferences in children as young as 24 months, this study gathered data from the parents of 17 - to 19month-old first-born infants, before those gender differences are well-established. Parents were asked to provide information regarding the toy choices and play behavior 
of their infants, allowing for a comparison to determine if there is any relation between the infants' gender-typed play behavior and the personal characteristics of the parent, specifically the parent's gender-role orientation.

The aim of the present study was to evaluate the following research questions and specific hypotheses:

\section{Research Questions}

1. Is there a relation between a parent's gender-role orientation and the gender-typing of the toys he or she provides for the child? The rationale behind this research question is that, as other behaviors are related to a person's gender-role orientation, so will the parent's toy purchasing behavior be related.

Hypothesis 1. Of the last 10 toys the parent purchased for his or her child, parents with a traditional gender-role orientation (i.e., feminine for mothers and masculine for fathers) will have purchased more same-gender-typed toys and fewer cross-gender-typed toys than parents with a nontraditional gender-role orientation (i.e., masculine, androgynous, undifferentiated for mothers and feminine, androgynous, and undifferentiated for fathers), who will have purchased approximately equal numbers of same-, and cross-gender-typed toys. Hypothesis 2. Parents with a traditional gender-role orientation will report being more likely to provide same-gender-typed toys and less likely to provide crossgender-typed toys for their child in the future than will parents with a nontraditional gender-role orientation, who will report being equally likely to provide same- and cross-gender-typed toys. 
2. Are there relations between the parent's gender-role orientation and his or her reported responses to the child's play with cross-gender-typed toys and with samegender-typed toys? The rationale behind this research question is that the encouragement and discouragement of play with some toys that parents report they provide will differ, depending upon their gender-role orientation. Further, the encouragement and discouragement from the parent may in turn affect the play behavior of the children.

Hypothesis 3. Parents who have a traditional gender-role orientation will report that they provide more negative feedback to play with cross-gender-typed toys and more positive feedback to play with same-gender-typed toys than parents who have a nontraditional gender-role orientation. 


\section{Methods}

\section{Participants}

Participants included 61 parents (mothers $n=46$, fathers $n=15$ ) of 17 - to 19month-old first-born infants. Participants were recruited from Morgantown, Wheeling, Parkersburg and the surrounding areas. Potential participants were identified via records from the local courthouses (for Morgantown and the surrounding areas) and via leads purchased from InfoUSA, a mailing list company (for Wheeling and Parkersburg). Potential participants were initially contacted via an introductory letter, which was then followed up by a phone call if the recipient had not responded to the letter. Those who were interested in participating were mailed the measures for completion.

Approximately 750 introductory letters were mailed out to families identified via courthouse records, with about a $10 \%$ response rate. Phone numbers were located for approximately half the families; however most of the families contacted via phone had older children, which rendered them ineligible for this study. The mailing list yielded 888 names; however 200 of the letters mailed were returned as undeliverable. Of the remaining letters, only one response was received. Phone calls to those families whose phone numbers could be located found that the families had older children or no children at all.

In addition, flyers about the study (see Appendix D) were posted at local stores, including Kroger, Giant Eagle, Target, and Pinocchio's Toy Store, and daycare centers with contact information for anyone who was interested in participating. One response was received from this manner of recruitment; however that person did not return her data packet. Attempts were also made to recruit from undergraduate psychology 
classes, although the attempts yielded no participants. In total, 88 packets were mailed out to interested individuals, of which 61 packets were returned. A total of 45 families participated, as all of the fathers were from families in which the mothers also participated and there was one mother with twins who filled out a data packet for each child.

\section{Measures}

The following measures were included in the questionnaire packets mailed to participants. The ordering of the questionnaires in the mailed packets was the same as the order in which the measures are discussed below.

Toy/Play Questionnaire. This questionnaire was constructed by the researcher specifically for the purposes of this study. Parents were asked to complete a questionnaire that included questions regarding their child's favorite items, their child's play behavior with toys already owned, whether or not they would provide certain toys for their children, etc. (see Appendix F). Not all of the questions were coded for specific hypotheses but were utilized for exploratory purposes not related to the current study. The specific coding process was as follows. For hypothesis 2 , the dependent variable, Likelihood of Providing Toy, came from item 11, which consisted of a list of 70 toys ( 25 masculine-typed, 25 feminine-typed, and 20 gender-neutral). This list of toys had been extracted from the much larger list that Campenni (1999) had used. All of the toys extracted from that study and used in the present study had also been rated by Campenni's participants as appropriate for children under 2 years of age. Item 11 asked participants to rate how likely they would be to provide their child with each of the toys listed, using a 5-point Likert-type scale with 1 being "extremely unlikely" to 5 being 
"extremely likely." Average likelihood ratings for the masculine- and feminine-gendertyped categories were calculated for use in the analysis. For hypothesis 3 , the dependent variable, Parental Feedback, came from the coding of item 12, which consisted of the same list of toys as item 11 and asked participants to rate their likelihood of encouraging their child to play with each of the toys using a 5-point Likerttype scale with 1 being "extremely unlikely to encourage play", 3 being "equally likely to encourage or discourage play," and 5 being "extremely likely to encourage play." An average feedback score was obtained for both the masculine- and feminine-typed toy categories for use as the dependent variables.

For hypothesis 1 , the dependent variables, number of masculine-typed toys and number of feminine-typed toys provided, was obtained from item 9 . For item 9 , participants were asked to identify the last 10 toys that they purchased for the child. Because not all parents listed 10 toys, a percentage of masculine- and feminine-typed toys were obtained for each participant, and those percentages were used as the dependent variables. If the toys listed were included in the Campenni (1999) study, then the ratings from that study were used to determine if each toy was masculine or feminine. The toys listed that were not included in the Campenni study were coded as masculine-typed, feminine-typed, or gender-neutral by the researcher, another graduate researcher, and two undergraduate research assistants. The coders were asked to identify which toys were mostly for boys (masculine-typed), equally for boys and girls (neutral), or mostly for girls (feminine-typed). Examples given to the coders included Barbie and a tea set for feminine-typed toys, educational books and crayons for neutral toys, and a football and Batman for masculine-typed toys. Kappa coefficients (K) were 
used to establish and assess reliability of coding between the researcher and the other three coders. Kappa coefficients were used because they provide information about inter-rater reliability by concentrating exclusively on the amount of agreement between coders (Howell, 2002).

To determine the inter-rater reliability in the present study, the three coders each coded $50 \%$ of the data, which was then compared with the researcher's ratings. The overall agreement between each of the coders and the researcher as measured by Kappa coefficients were $.95, .77$, and .77 .

Toddler Temperament Questionnaire. The Toddler Temperament Scale (TTS; Fullard, McDevitt, \& Carey, 1984) was used to assess the parents' perception of the temperament of the toddlers. This measure consists of 97 items regarding the temperament of the toddler. These items fall under nine categories (activity, rhythmicity, approach, adaptability, intensity, mood, persistence, distractibility, and threshold) with internal consistency ranging from .53 (adaptability) to .86 (approach) and test-retest reliability ranging from .69 (distractibility) to .89 (approach). While there were no specific hypotheses regarding toddler temperament, the measure was utilized to explore the possibility of a bidirectional socialization process, in which characteristics of the child are influencing the parents' choices of which types of toys to provide for the child and the type of feedback the parents give to the gender-typed play of their child.

Gender Role. The Bem Sex-Role Inventory (BSRI; Bem, 1974) was used to assess the gender-role orientation of participants. This measure consists of 60 adjectives for participants to rate using a 7-point Likert-type scale ranging from 1 (never or almost never true) to 7 (always or almost always true). The 60 items include 20 that 
are stereotypically masculine (e.g., athletic, dominant), 20 that are stereotypically feminine (e.g., tender, sensitive to the needs of others), and 20 that are considered gender-neutral (e.g., sincere, happy). The current method of scoring the BSRI is to determine high and low scores on the masculine and feminine scales by performing a median split. However, when working with a small sample, that procedure results in forcing individuals into categories that may not actually exist in that sample. The BSRI for this study was scored based on a suggestion made by Sedney (1981) in response to the above difficulty. An ANOVA was conducted for each participant, comparing his or her ratings on masculine items to his or her ratings on feminine items. Participants whose scores on the two scales were significantly different, with the average rating of feminine items higher than the average rating of masculine items were categorized as having a feminine gender-role orientation. When the average rating of masculine items was significantly higher than the feminine items, the participant was categorized as having a masculine gender-role orientation. Mothers with a feminine gender-role orientation and fathers with a masculine gender-role orientation were categorized as having a traditional gender-role orientation. The remaining participants were categorized as having a nontraditional (including masculine, androgynous, or undifferentiated for mothers and feminine, androgynous, or undifferentiated for fathers) gender-role orientation.

Prior research with the BSRI has shown adequate internal consistency (ranging from .80 to .86 ) and test-retest reliability (ranging from .90 to .93 ; Bem, 1974). The internal consistency for this study was .88 for the masculine scale and .85 for the feminine scale. More recent research replicated the original work by Bem (1974) to 
assess the current validity of the scale, revalidating all but two of the items ("loyal" and "child-like" on the femininity scale) and finding that the internal consistency is still high (.95 on the masculinity scale and .92 on the femininity scale; Holt \& Ellis, 1998). Despite the fact that "loyal" and "child-like" were not revalidated, current research has continued using these items on the BSRI (e.g., Konrad \& Harris, 2002; Pickard \& Strough, 2003). Thus, these two items remained on the BSRI for the purpose of this study (see Appendix G).

Parental Demographic Information. Parents were asked to complete a demographics questionnaire which included questions regarding marital status, education level, current occupation for themselves and the child's other parent, and the amount of time spent interacting with the child in an average day (see Appendix $\mathrm{H}$ ). Procedure

Possible participants, who were identified as outlined in the Participants section, were contacted with an introductory letter (see Appendix A) that included a brief description of the study. The letter was followed up with a phone call (see Appendix E), at which point the parent was asked if he or she would like to participate. Those parents who expressed interest in participating were mailed a packet that included a cover letter (see Appendix C), consent forms, the toy/play questionnaire, the Toddler Temperament Scale, the BSRI, and the parental demographics questionnaire. Participants were asked to return the completed forms using the included postage-paid return envelope. If both parents participated, they were provided with two return envelopes and asked to return their packets separately. Participants were compensated with a $\$ 10$ gift certificate to Target. Only one gift certificate was provided per family, even if both parents 
participated. One participant declined the gift certificate, stating that she did not ever go to Target. 


\section{Results}

\section{Sample Characteristics}

Demographic characteristics of the study sample divided by parent sex are presented in Table 1. Seventy-five percent of the sample was mothers and the majority $(92 \%)$ of the sample was Non-Hispanic Caucasian. Most of the mothers $(80 \%)$ and all of the fathers were married, and $41 \%$ had a college degree or higher education level. There were 23 sons and 23 daughters, and the mean ages for the children were 18.61 months for sons and 18.72 months for daughters $(S D=.97$ and $S D=.79$, respectively). A summary of the breakdown of the participant gender-role orientation is presented in Table 2.

\section{Preliminary Analyses}

Because all of the fathers who participated in this study were married to one of the mothers who also participated, correlations between the responses of mothers and fathers from the same families, with child sex controlled, were calculated to determine if the parents were providing similar answers to the questions from which the dependent variables were obtained. The analyses, which are summarized in Table 3, showed that the recent provision by mothers and fathers of masculine-typed toys and feminine-typed toys were significantly and strongly related. However, the correlations between mothers and fathers for the likelihood of providing masculine- and feminine-typed toys and the feedback to play with masculine- and feminine-typed toys were not significant.

Correlations between the dependent variables of all mothers and fathers, with child sex controlled, were also calculated. The results, which are summarized in Tables 4 and 5 , indicated that the likelihood of providing feminine-typed toys was significantly 
correlated with the feedback provided to play with feminine-typed toys for both mothers and fathers. In addition, the likelihood of providing masculine-typed toys was significantly correlated with the feedback to play with masculine-typed toys for both mothers and fathers. The likelihood of providing feminine-typed toys was also significantly related to the recent provision of feminine-typed toys for both mothers and fathers. However, feedback to play with feminine-typed toys was significantly related to the provision of feminine-typed toys for mothers only. In addition, the relation between the likelihood of providing masculine-typed toys and the recent provision of masculinetyped toys and the relation between feedback to play with masculine-typed toys and the recent provision on feminine-typed toys were significant only for fathers.

Finally, prior to conducting the analyses for any of the hypothesis, the data for each hypothesis was checked to make sure that the assumptions of the ANOVA were upheld. The assumption for having a normal distribution was tested using the Kolmogrov-Smirnov and Shapiro-Wilk statistics, and the assumption for homogeneity of variance was tested with the Levene statistic.

Analyses of Hypothesis One

The first research question addressed in this study concerned whether or not the toy purchasing behavior of mothers and fathers would be related to their gender-role orientation. Hypothesis 1, which stated that parents with a traditional gender-role orientation would report purchasing more same-gender-typed toys (i.e., masculinetyped toys for boys and feminine-typed toys for girls) and fewer cross-gender-typed toys (i.e., feminine-typed toys for boys and masculine-typed toys for girls) than parents with a nontraditional gender-role orientation, who would report purchasing approximately equal 
numbers of same- and cross-gender-typed toys, was assessed using 2 (Parent's Gender-Role Orientation) $\times 2$ (Child Sex) ANOVAs with the percentage of recently provided toys that were masculine and feminine as the dependent variables.

The participants listed a total of 507 toys, 143 of which were determined to be masculine, 90 of which were determined to be feminine, and 284 of which were determined to be neutral. Participants listed an average of 8.33 toys, with a range from 3 to 10 . Most of the participants (66\%) listed 10 toys. See Table 6 for a list of all the toys, which have been grouped into like categories (e.g., balls, regardless of color or character endorsement) for simplification, listed by the participants. The third category of neutral toys was not used in the analysis so as to prevent linear dependence among the dependent variables. Because of the unequal numbers of mothers and fathers in the study and the potential for shared variance due to rating the same child, mothers and fathers were analyzed separately (see Table 7).

Although it was hypothesized that there would be an interaction between the two independent variables, only the main effect for Child Sex in each analysis was significant, with the exception of fathers provision of masculine toys. Mothers reported recently providing more masculine-typed toys for their sons than their daughters, $F(1$, $42)=21.25, p=.00$, and more feminine-typed toys for their daughters than their sons, $F$ $(1,42)=24.13, p=.00$. Fathers had recently provided more feminine-typed toys for their daughters than their sons, $F(1,11)=7.13, p=.02$. The effect for masculine-typed toys for fathers approached significance, with fathers tending to provide more masculine-typed toys for their sons than their daughters, $F(1,11)=4.09, p=.07$. The lack of significance for this effect is most likely due to the small number of participants 
$(n=6)$ and the resulting lack of power (power $=.46)$. See Table 8 for means and standard deviations for these analyses.

In addition, there was a significant main effect for Gender-Role Orientation for fathers' recent provision of feminine-typed toys, such that traditional fathers had recently provided more feminine-typed toys than nontraditional fathers, $F(1,11)=5.03, p=.05$ (see Table 9 for means and standard deviations).

Analyses of Hypothesis Two

Hypothesis 2, that parents with a traditional gender-role orientation would report being more likely to provide same-gender-typed toys and less likely to provide crossgender-typed toys for their child in the future than would parents with a nontraditional gender-role orientation, who would report being equally likely to provide same- and cross-gender-typed toys, was also assessed via 2 (Parent's Gender-Role Orientation) x 2 (Child Sex) ANOVAs, with mothers and fathers assessed separately. The dependent variables for these analyses were the parents' likelihood of providing masculine and feminine toys for their children in the next six months (see Table 10).

As with the first hypothesis, the main effects for Child Sex were significant. Mothers reported being more likely to provide masculine-typed toys in the future for their sons than their daughters, $F(1,42)=60.99, p=.00$, and being more likely to provide feminine-typed toys in the future for their daughters than their sons, $F(1,41)=29.41, p$ $=.00$. Fathers also reported being more likely to provide feminine-typed toys in the future for their daughters than their sons, $F(1,11)=9.46, p=.01$. As with the first hypothesis, the effect for fathers' likelihood of providing masculine-typed toys approached significance, $F(1,11)=4.08, p=.07$, in the expected direction of fathers 
being more likely to provide masculine-typed toys for sons than daughters (see Table 11 for means and standard deviations). Although the interaction for mothers' reports of their likelihood to provide feminine-typed toys in the future approached significance, $F$ $(1,41)=3.49, p=.07$, the trend seen was contrary to the hypothesis, such that nontraditional mothers reported being more differential in their likelihood of providing feminine-typed toys for their daughters than their sons than did traditional mothers. Analyses for Hypothesis Three

The second research question addressed by this study concerned a possible relation between the parent's gender-role orientation and that parent's reported responses to the child's play with masculine- and feminine-typed toys. Hypothesis 3, which stated that parents who have a traditional gender-role orientation would report that they would provide more negative feedback to cross-gender-typed play and more positive feedback to play with same-gender-typed toys than parents who have a traditional gender-role orientation, was evaluated using 2 (Parent Gender-Role Orientation) $\times 2$ (Child Sex) ANOVAs with mothers and fathers assessed separately. The average response given to play with masculine- and feminine-typed toys were the dependent variables. For mothers, the main effects for Child Sex were significant for both masculine- and feminine-typed toys (see Table 12). Mothers reported being more likely to encourage play with masculine-typed toys for their sons than their daughters, $F$ $(1,41)=7.32, p=.01$, and more likely to encourage play with feminine-typed toys for their daughters than their sons, $F(1,41)=35.07, p=.00$. Fathers reported being more likely to encourage play with feminine-typed toys for their daughters than their sons, $F$ $(1,11)=5.23, p=.04$, although there was no difference in the feedback that fathers 
provided to their sons and daughters for play with masculine-typed toys (see Table 13 for means and standard deviations). None of the interactions between parent gender role orientation and child sex were significant.

\section{Exploratory Analyses}

In order to investigate the possibility of parents altering their toy purchasing behavior or feedback provided to their child's play behavior based on their perception of their child's temperament, or specific temperamental characteristics, partial correlations, with child sex controlled, were conducted to determine whether there were any relations between the child's temperament, as assessed by the Toddler Temperament Scale (TTS), and the dependent variables. Included in the correlation matrix, which is summarized in Tables 14 and 15, were each of the subscales from the Toddler Temperament Scale, the percentage of masculine- and feminine-typed toys the mothers had recently provided for their children, the mother's report of average likelihood for providing masculine- and feminine-typed toys for their child in the next 6 months, and the mother's report of the likelihood of their child playing with masculine- and femininetyped toys. As all of the Toddler Temperament Scales were completed by the child's mother, parent sex was not included as a variable in the correlations between the TTS and the other variables.

Analyses revealed that the mothers' likelihood of providing masculine-typed toys in the future was related to the mothers' ratings of the child's distractibility, $r(40)=.32, p$ $=.04$, such that the more distractible the mother thought the child was, the more likely she was to provide masculine-typed toys in the future. In addition, the mothers' likelihood of providing feminine-typed toys in the future was related to the mothers' 
ratings of the child's distractibility, $r(40)=.40, p=.01$, and the mothers' ratings of the child's activity level, $r(40)=.34, p=.02$, such that the more distractible and active the mother thought the child was, the more likely the she was to provide feminine-typed toys in the future. With respect to the toys recently purchased, the more adaptable the mother rated the child, the more masculine-typed toys the mother had recently purchased for her child, $r(40)=-.30, p=.05$. The more distractible the child and the lower the child's sensory threshold, the more feminine-typed toys the mother had recently purchased for her child, $r(40)=.36, p=.02$ and $r(40)=.37, p=.02$, respectively. With respect to the feedback to play with feminine-typed toys, the less adaptable and the lower the child's sensory threshold, the more likely the mother was to encourage play with feminine-typed toys, $r(40)=.36, p=.02$ and $r(40)=.36, p=.02$, respectively. 


\section{Discussion}

This study investigated whether or not a parent's gender-role orientation is related to the gender-typing of the toys that their children are playing with or may play with in the future, in particular to determine whether or not a parent's gender-role orientation is a better predictor than child sex of the gender socialization of the child that occurs in toy play situations. Although the hypotheses for this study were not supported, there are several results from this study that are notable and worth discussing. Recently Provided Gender-Typed Toys for Children

The first research question addressed the relation between the parent's genderrole orientation and the gender-typing of the toys that the parent recently provided for the child (hypothesis 1) and the gender-typing of the toys that the parent identified as likely to provide for his or her child in the next 6 months (hypothesis 2). While the hypothesized interactions for the first research question were not significant, it is important to note that child sex was significant for both hypotheses. With respect to hypothesis 1 , the results showed that mothers had recently provided more masculinetyped toys for their sons than their daughters, and more feminine-typed toys for their daughters than their sons. Fathers had recently provided more feminine-typed toys for their daughters than their sons, and there was a trend toward fathers providing more masculine-typed toys for their sons than their daughters.

The obtained results seem to indicate that, rather than providing toys based on their individual internalization of masculine and feminine characteristics, parents are providing toys based on masculine and feminine stereotypes. Bem $(1974 ; 1977)$ has stated, and further research has supported (Cheng, 2005; Heilbron \& Han, 1986; Pyke, 
1985; Shimonaka, Nakazato, Kawaai, \& Sato, 1997) that the healthiest and most adaptive gender-role orientation is androgynous, because it allows for a greater number of characteristics to be drawn from for any given situation. If one accepts Bem's claim, by providing significantly more same-gender typed toys than cross-gender-typed toys for their children, parents may be hindering their children's in development of androgyny by limiting the opportunities that the child would have to develop cross-gender characteristics. However, it is not surprising that parents would be providing more feminine-typed toys for daughters than sons and more masculine-typed toys for sons than daughters, as this difference is consistent with the literature (Kim, 2002; O'Brien \& Huston, 1985; Pomerleau, Bolduc, Malcuit, \& Cossette, 1990; Rheingold \& Cook, 1975; Zammuner, 1987).

While it was expected that this result would be obtained for parents with a traditional gender-role orientation (i.e., masculine for fathers and feminine for mothers), but not for parents with a nontraditional gender-role orientation (i.e., feminine, androgynous, and undifferentiated for fathers and masculine, androgynous, and undifferentiated for mothers), the effect for Gender-Role Orientation was only significant for fathers' provision of feminine-typed toys, such that traditional fathers provided a greater percentage of feminine-typed toys than nontraditional fathers. This finding was somewhat in line with the hypothesis, although the interaction of Gender-Role Orientation and Child Sex was not present, and was consistent with McHale, Bartko, Crouter, and Perry-Jenkins (1990), which found that children of more traditional fathers were more likely to engage in same-gender-typed household chores than children of less traditional fathers. If traditional fathers are trying to preserve the gender-role 
stereotypes, then it makes sense that they would provide more feminine-typed toys than nontraditional fathers, particularly since fathers may be more differential than mothers in the treatment of their sons and daughters (Maccoby, 1998). However, one must also evaluate this finding carefully, as it suggests that traditional fathers are buying more feminine-typed toys than non-traditional fathers for their sons as well as their daughters. Likelihood of Providing Gender-Typed Toys for Children in the Future

Similar results were obtained for the second hypothesis. Mothers reported a greater likelihood of providing masculine-typed toys for their sons than their daughters and a greater likelihood of providing feminine-typed toys for their daughters than their sons. Fathers also reported a greater likelihood of providing feminine-typed toys for their daughters than their sons, and there was a trend present for fathers having a greater likelihood of providing masculine-typed toys for their sons than their daughters. As with the results from the first hypothesis, the results seem to indicate that, rather than providing toys based on their individual internalization of masculine and feminine characteristics, parents are providing toys based on masculine and feminine cultural stereotypes, which may be hindering children in developing their androgyny. This difference though, as with the first hypothesis, is still consistent with the literature (Kim, 2002; O’Brien \& Huston, 1985; Pomerleau, Bolduc, Malcuit, \& Cossette, 1990; Rheingold \& Cook, 1975; Zammuner, 1987).

There was also a trend for an interaction with respect to mothers' likelihood of providing feminine-typed toys, although this interaction was opposite of the expectation based on the hypotheses. Mothers with a feminine gender-role orientation, while still reporting a greater likelihood of providing feminine-typed toys for their daughters than 
their sons, were less differential than mothers with a nontraditional gender-role orientation, who reported being much more likely to provide feminine-typed toys for their daughters than their sons in the next 6 months. However, it would seem that, for feminine-typed toys at least, mothers' likelihood of providing toys in the future is also being influenced by the mother's gender-role orientation. Interestingly, though, and quite the opposite from expectations, mothers with a traditional gender-role orientation reported being more likely to provide feminine-typed toys for their sons than mothers with a nontraditional gender-role orientation. This trend is surprising given that there is a stronger censure for boys playing with feminine-typed toys than for girls playing with masculine-typed toys (Maccoby, 1998), thus it would seem that nontraditional mothers should be more likely to provide feminine-typed toys for their sons than traditional mothers.

Feedback Provided to Children for Play with Gender-Typed Toys

The second research question was designed to address the actual socialization processes that the parents were using with their children, specifically through their encouragement of play with gender-typed toys. Mothers reported being more likely to encourage play with masculine-typed toys for their sons than their daughters, and more likely to encourage play with feminine-typed toys for their daughters than their sons, while fathers reported being more likely to encourage play with feminine-typed toys for their daughters than their sons. The finding for feminine-typed toys is not surprising given the stronger censure for cross-gender play for males than for females and the fear often cited by parents that sons playing with feminine-typed toys will become homosexual (Maccoby, 1998). It is surprising that mothers were more likely to 
encourage play with masculine-typed toys for sons than daughters, when the same difference was not seen for fathers, particularly in light of the idea that fathers are more differential in their treatment of their children than mothers, and that fathers act as the masculinizing agents for their sons (Maccoby, 1998). However, this result may be due to the fact that fathers would be more likely to play with masculine-typed toys than feminine-typed toys when playing with their children, as masculine-typed toys are typically considered to be more active, and feminine-typed toys more passive (Denmark, Rabinowitz, \& Sechzer, 2005), and fathers are more likely to engage in rough-and-tumble play with their children than mothers (Hughes, 1999). Additionally, the lack of a result for the fathers may be due to the difference in sample sizes, as more mothers participated than fathers. The fewer number of fathers participating resulted in much lower power, or ability to find a significant effect if it actually exists.

\section{Exploratory Analyses}

While there were no specific hypotheses that addressed the possibility that parents may be adjusting their toy purchasing behaviors or feedback in response to their perceptions of their child's temperament, to see if characteristics of the child were influencing the parents' likelihood of providing gender-typed toys for their children and the gender-typing of the toys that parents reported encouraging and discouraging play for, correlations were conducted with the scores on the subscales of the Toddler Temperament Scale and the different measures of gender-socialization used in the three hypotheses previously discussed. Results showed some correlations between the subscales of the Toddler Temperament Scale and the various dependent variables, indicating the possibility that mothers might be altering their toy provision and feedback 
to play based on certain characteristics of the child. The more active the child, the more likely the mother was to provide feminine-typed toys in the future. Although it seems that mothers of active children would be more likely to provide masculine-typed toys, since masculine-typed toys are generally considered to be more active (Denmark, Rabinowitz, \& Sechzer, 2005), it may be that mothers of active children are trying to limit the child's activity by providing feminine-typed toys, which are generally considered to be more passive (Denmark, Rabinowitz, \& Sechzer, 2005). Mothers had also recently provided more feminine-typed toys and were more likely to provide feminine-typed toys to their children in the future when they rated their children as being more distractible, which could be due to the mothers responding to their child's distractibility and trying to provide toys that would either decrease their child's distractibility, or at the very least not increase it even more. According to Singer (1994), the simpler or less structured the toy, the more active and lengthy the imaginative play scenario in which the child engages, and feminine-typed toys are more likely to be simple and less structured. Thus, mothers may be trying to provide toys that will encourage lengthy play sessions with fewer toys, as opposed to more toys.

In addition, mothers of children who adapted more quickly had recently provided more masculine-typed toys for their children and were less likely to encourage play with feminine-typed toys. Because of the more active and elaborate aspects of the masculine-typed toys (Denmark, Rabinowitz, \& Sechzer, 2005; Singer, 1994), children who adapt more quickly may respond better to them, so mothers provide more masculine-typed toys. In addition, the mothers are less likely to encourage play with 
feminine-typed toys, which may be more appropriate for more gradually adapting children.

Finally, the lower the child's sensory threshold, the greater the percentage of feminine-typed toys the mother had recently provided for her child and the more likely she was to encourage play with feminine-typed toys. When looking at the properties typically found in masculine- and feminine-typed toys, feminine-typed toys are principally associated with nurturance, domesticity, and attractiveness, such that the toys are more attractive, not that they necessarily encourage a focus on the child's own appearance. Masculine-typed toys, on the other hand are principally associated with aggression, competitiveness, and violence. In addition, masculine-typed toys are more likely to move on their own or roll across the floor (e.g., trucks, balls) than are femininetyped toys (Blakemore \& Centers, 2005). Thus, it seems likely that a child with a lower sensory threshold would respond better to feminine-typed toys, and respond more negatively to masculine-typed toys that might overload the child's senses. If mothers are responding to the child's threshold, then it would make sense that they would be more likely to encourage play with feminine-typed toys and provide fewer masculine-typed toys to children with low thresholds.

\section{Limitations of the Study and Future Directions}

There are several limitations of this study that must be addressed as qualifications of the results. The first is the small sample size for this study. Many different methods of subject recruitment were used, including purchasing mailing lists and posting fliers in local stores, to try to increase the sample size. The recruitment area was expanded from Morgantown to include Clarksburg and Fairmont, where names 
were obtained from the courthouses, and Parkersburg and Wheeling, where names were purchased from a mailing list company. However, the mailing lists provided no return of participants. There was an increase when Clarksburg and Fairmont were included; however, not everyone who stated being willing to participate and was mailed a questionnaire packet returned a completed packet. In fact, only 61 of the 88 packets that were mailed out were returned. This limited sample size affected the ability to find significant results if they were there to find, particularly with respect to the hypothesized interactions. As reported in the tables for each hypothesis, the power level observed for the interactions ranged from .05 to .45 . A larger sample size would allow for greater power, which would mean a greater chance of finding significant results if they were there.

In addition, the study used only self-report measures, which may not have provided a completely accurate account of the effects as parents may have altered their reports based on social desirability. While the questionnaires did not contain items that would normally be considered sensitive, because parents thought the study was investigating the relation between personality characteristics and parents and children, and the effects of those on the child's play behavior, the parents may have wanted to portray themselves and their children in a better light and thus not reported behaviors that would likely violate existing social mores and stereotypes.

It is also important to note that the characteristics of the participants may not be representative of the population as a whole. If the sample is not representative of the general population, then that would limit the ability to generalize the findings from the 
current study to the general population as a whole and the results could only be generalized to individuals who match the characteristics of the current sample.

Despite the lack of support for the hypotheses in the present study, future studies that look at a child's play with gender-typed toys would benefit from taking the parent's gender-role orientation into account. The sample size of the present study greatly limited the ability of the researcher to adequately test the hypothesized interactions, and future studies utilizing larger, more representative samples should be done.

In addition, future studies would benefit from using more direct observations of child behavior, in addition to the traditional self-report measures obtained from parents. As shown with the exploratory analyses, there does appear to be some reciprocal socialization between the mother and child occurring with respect to a child's gendertyped play. However, as the results were correlations, one is unable to determine causation. In addition, as no measures were collected from the child, it is unknown if the apparent bidirectional process is actually a bidirectional process, or if it is a result the parent's beliefs about what their child would do. 


\section{References}

Adams, C. H. (1982). Sex-role orientation and psychological adjustment: Comparison of MMPI profiles among college women and housewives. Journal of Personality Assessment, 46, 607-613.

Barberá, E. (2003). Gender schemas: Configuration and activation processes. Canadian Journal of Behavioural Science, 35, 176-184.

Bauer, C. C. \& Baltes, B. B. (2002). Reducing the effects of gender stereotypes on performance evaluations. Sex Roles, 47, 465-476.

Beal, C. R. (1994). Boys and girls: The development of gender roles. New York: McGraw-Hill, Inc.

Bem, S. L. (1974). The measurement of psychological androgyny. Journal of Counseling and Clinical Psychology, 42, 155-162.

Bem, S. L. (1977). On the utility of alternative procedures for assessing psychological androgyny. Journal of Consulting and Clinical Psychology, 45, 196-205.

Bem, S. L. (1981). Gender schema theory: A cognitive account of sex typing. Psychological Review, 88, 354-364.

Blakemore, J. E. O., \& Centers, R. E. (2005). Characteristics of boys' and girls' toys. Sex Roles, 53, 619-633.

Bowers, S. P. (1999). Gender role identity and the caregiving experience of widowed men. Sex Roles, 41, 645-655.

Campenni, C. E. (1999). Gender stereotyping of children's toys: A comparison of parents and nonparents. Sex Roles, 40, 121-138. 
Cheng, C. (2005). Process underlying gender-role flexibility: Do androgynous individuals know more or know how to cope? Journal of Personality, 73, 645-673.

Cleveland, J. N., Stockdale, M., \& Murphy, K. R. (2000). Women and men in organizations: Sex and gender issues at work. Mahwah, NJ: Erlbaum.

Condry, J., \& Condry, S. (1976). Sex differences: A study in the eye of the beholder. Child Development, 47, 812-819.

Darley, J. M. \& Fazio, R. H. (1980). Expectancy confirmation process arising in the social interaction sequence. American Psychologist, 35, 867-881.

Denmark, F. L., Rabinowitz, V. C., \& Sechzer, J. A. (2005). Engendering psychology: Women and gender revisited ( $2^{\text {nd }}$ ed.). New York: Prentice Hall.

Dixon, Jr., W. E., \& Smith, P. H. (2003). Who's controlling whom? Infant contributions to maternal play behavior. Infant and Child Development, 12, 177-195.

Eccles, J. S., Frome, P., Yoon, K. S., Freedman-Doan, C., \& Jacobs, J. (2000). Genderrole socialization in the family: A longitudinal approach. In T. Eckes \& H. M. Trautner (Eds.), The developmental social psychology of gender (pp. 333-360). Mahwah, NJ: Lawrence Earlbaum Associates.

Ex, C. T. G. M. \& Janssens, J. M. A. M. (1998). Maternal influences on daughters' gender role attitudes. Sex Roles, 38, 171-186.

Fagot, B. I., \& Hagan, R. (1991). Observations of parent reactions to sex-stereotyped behaviors: Age and sex effects. Child Development, 62, 617-628.

Fagot, B. I., Hagan, R., Leinbach, M. D., \& Kronsberg, S. (1985). Differential reactions to assertive and communicative acts of toddler boys and girls. Child Development, 56, 1499-1505. 
Fagot, B. I. \& Leinbach, M. D. (1989). The young child's gender schema: Environmental input, internal organization. Child Development, 60, 663-672.

Fagot, B. I., Rodgers, C. S., \& Leinbach, M. D. (2000). Theories of gender socialization. In T. Eckes \& H. M. Trautner (Eds.), The developmental social psychology of gender (pp. 65-89). Mahwah, NJ: Lawrence Earlbaum Associates.

Fullard, W., McDevitt, S. C., \& Carey, W. B. (1984). Assessing temperament in one- to three-year-old children. Journal of Pediatric Psychology, 9, 205-217.

Gordon, B. N. (1981). Child temperament and adult behavior: An exploration of 'goodness of fit.' Child Psychiatry \& Human Development, 11, 167-178.

Heilbron, A. B., \& Han, Y. L. (1986). Sex differences in the adaptive value of androgyny. Psychological Reports, 59, 1023-1026.

Helgeson, V. S. (2004). Psychology of gender ( $2^{\text {nd }}$ ed. $)$. New Jersey: Prentice Hall. Holt, C. L., \& Ellis, J. B. (1998). Assessing the current validity of the Bem Sex-Role Inventory. Sex Roles, 39, 929-941.

Howell, D. C. (2002). Statistical methods for psychology ( $5^{\text {th }}$ ed.). California: Duxbury. Hughes, F. P. (1999). Children, play, and development ( $3^{\text {rd }}$ ed.). New York: Allyn and Bacon.

Intons-Peterson, M. J., \& Reddel, M. (1984). What do people ask about a neonate? Developmental Psychology, 20, 358-359.

Karniol, R., Grosz, E., \& Schorr, I. (2003). Caring, gender role orientation and volunteering. Sex Roles, 49, 11-19. 
Karraker, K. H., Vogel, D. A., \& Lake, M. A. (1995). Parents' gender-stereotyped perceptions of newborns: The eye of the beholder revisited. Sex Roles, 33, 687701.

Kim, M. (2002). Parents' perceptions and behaviors regarding toys for young children's play in Korea. Education, 122, 793-807.

Kimlicka, T. M., Sheppard, P. L., \& Wakefield, J. A. (1987). Relationship between psychological androgyny and self-actualization tendencies. Psychological Reports, 61, 443-446.

Konrad, A. M., \& Harris, C. (2002). Desirability of the Bem Sex-Role Inventory items for women and men: A comparison between African Americans and European Americans. Sex Roles, 47, 259-271.

Leeb, R. T., \& Rejskind, F. G. (2004). Here's looking at you kid! A longitudinal study of perceived gender differences in mutual gaze behavior in young infants. Sex Roles, 50, 1-14.

Leflamme, D., Pomerleau, A., \& Malcuit, G. (2002) A comparison of fathers' and mothers' involvement in childcare and stimulation behaviors during free-play with their infants at 9 and 15 months. Sex Roles, 47, 507-518.

Leinbach, M. D., \& Fagot, B. (1986). Acquisition of gender labeling: A test for toddlers. Sex Roles, 15, 655-666.

Lindsey, E. W., \& Mize, J. (2001). Contextual differences in parent-child play: Implications for children's gender role development. Sex Roles, 44, 155-176.

Lytton, H., \& Romney, D. M. (1991). Parents' differential socialization of boys and girls: A meta-analysis. Psychological Bulletin, 109, 267-296. 
Maccoby, E. E. (1998). The two sexes: Growing up apart, coming together. Cambridge, Massachusetts: Harvard University Press.

Maccoby, E. E., \& Jacklin, C. N. (1974). The psychology of sex differences. Stanford, California: Stanford University Press.

Martin, C. L., Eisenbud, L., \& Rose, H. (1995). Children's gender-based reasoning about toys. Child Development, 66, 1453-1471.

Martin, C. L., \& Little, J. K. (1990). The relation of gender understanding to children's sex-typed preferences and gender stereotypes. Child Development, 61, 14271439.

McHale, S. M., Bartko, W. T., Crouter, A. C., \& Perry-Jenkins, M. (1990). Children's housework and psychosocial functioning: The mediating effects of parents' sexrole behaviors and attitudes. Child Development, 61, 1413-1426.

Moen, P., Erickson, M. A., \& Dempster-McClair, D. (1997). Their mother's daughters? The intergenerational transmission of gender attitudes in a world of changing roles. Journal of Marriage and the Family, 59, 281-293.

Nelson, J. A., \& Simmerer, N. J. (1984). A correlational study of children's temperament and parent behavior. Early Child Development and Care,16, 231-250.

O’Brien, M., \& Huston, A. (1985). Development of sex-typed behavior in toddlers. Developmental Psychology, 21, 866-871.

Picariello, M. L., Greenberg, D. N., \& Pillemer, D. B. (1990). Children's sex-related stereotyping of colors. Child Development, 61, 1453-1460.

Pickard, J,. \& Strough, J. (2003). The effects of same-sex and other-sex contexts on masculinity and femininity. Sex Roles, 48, 421-432. 
Pomerleau, A., Bolduc, D., Malcuit, G., \& Cossette, L. (1990). Pink or blue:

Environmental gender stereotypes in the first two years of life. Sex roles, 22, 359-367.

Pyke, S. W. (1985). Androgyny: An integration [Special Issue]. International Journal of Women's Studies, 8, 529-539.

Raag, T. (1999). Influences of social expectations of gender, gender stereotypes, and situational constraints on children's toy choices. Sex Roles, 41, 809-831.

Raag, T., \& Rackliff, C. L. (1998). Preschoolers; awareness of social expectations of gender: Relationships to toy choices. Sex Roles, 38, 685-700.

Reeder, H. M. (2003). The effect of gender role orientation on same- and cross-sex friendship formation. Sex Roles, 49, 143-152.

Rheingold, H., \& Cook, K. V. (1975). The contents of boys' and girls' rooms as an index of parents' behavior. Child Development, 46, 459-463.

Roopnarine, J. L. (1986). Mothers' and fathers' behaviors toward the toy play of their infant sons and daughters. Sex Roles, 14, 59-68.

Rubin, J. Z., Provenzano, F. J., \& Luria, Z. (1974). The eye of the beholder: Parents' views on sex of newborns. American Journal of Orthopsychiatry, 44, 512-519.

Sedney, M. A. (1981). Comments on median split procedures for scoring androgyny measures. Sex Roles, 7, 217-222.

Shimonaka, Y., Nakazato, K., Kawaai, C., \& Sato, S. (1997). Androgyny and successful adaptation across the life span among Japanese adults. Journal of Genetic Psychology, 158, 389-400. 
Singer, J. L. (1994). Imaginative play and adaptive development. In J. H. Goldstein (Ed.), Toys, Play, and Child Development (pp. 6-26). New York: Cambridge University Press.

Spence, J. T. (1993). Gender-related traits and gender ideology: Evidence for a multifactorial theory. Journal of Personality and Social Psychology, 64, 624-635.

Stern, M., \& Karraker, K. H. (1989). Sex stereotyping of infants: A review of gender labeling studies. Sex Roles, 20, 501-522.

Wood, E., Desmarais, S., \& Gagula, S. (2002). The impact of parenting experience on gender stereotyped toy play of children. Sex Roles, 47, 39-49.

Zammuner, V. L. (1987). Children's sex-role stereotypes: A cross-cultural analysis. In P. Shaver \& C. Hendrick (Eds.), Review of personality and social psychology (Vol. 7, Newbury Park). CA: Sage. 
Table 1

Demographic Characteristics of Study Participants $(N=61)$

\begin{tabular}{|c|c|c|}
\hline Characteristic & Fathers $(n=15)$ & Mothers $(n=46)$ \\
\hline Mean Age (Standard Deviation) & $31.13(4.26)$ & $28.13(4.97)^{\mathrm{a}}$ \\
\hline \multicolumn{3}{|l|}{ Marital Status } \\
\hline Married & 15 & 37 \\
\hline Divorced & 0 & 3 \\
\hline Single, Never Married & 0 & 3 \\
\hline Cohabiting & 0 & 3 \\
\hline \multicolumn{3}{|l|}{ Education Level } \\
\hline Less than High School & 0 & 2 \\
\hline High School Graduate & 2 & 9 \\
\hline Some College & 6 & 17 \\
\hline College Graduate & 2 & 7 \\
\hline Some Grad. or Prof. School & 2 & 6 \\
\hline Completed Grad. or Prof. & 3 & 5 \\
\hline \multicolumn{3}{|l|}{ School } \\
\hline \multicolumn{3}{|l|}{ Race } \\
\hline Asian/Pacific Islander & 0 & 1 \\
\hline African American & 0 & 1 \\
\hline Hispanic & 0 & 3 \\
\hline Non-Hispanic Caucasian & 15 & 41 \\
\hline
\end{tabular}


(Table 1 continued)

\begin{tabular}{lcc}
\hline \multicolumn{1}{c}{ Characteristic } & Fathers $(\mathrm{n}=15)$ & Mothers $(\mathrm{n}=43)$ \\
\hline Mean for time playing with child & $2.71(1.20)$ & $5.60(2.03)$ \\
each day (SD) & & 19 \\
Does your child attend & 3 & 27 \\
daycare? & 12 & \\
Yes & & 16 \\
No & & 30 \\
Does your child have siblings? & 4 & \\
Yes & 11 & 8 \\
No & & 11 \\
Plan to have more children? & 9 & 27 \\
Yes & 2 & \\
No & 4 & \\
Unsure & & \\
\hline a $n=45$. & & \\
\end{tabular}


Table 2

Frequencies of Categories of Gender-Role Orientation by Participant Sex $(N=61)$

\begin{tabular}{lcccc}
\hline & \multicolumn{2}{c}{ Fathers $(n=15)$} & \multicolumn{2}{c}{ Mothers $(\mathrm{n}=46)$} \\
\cline { 2 - 5 } & Sons & Daughters & Sons & Daughters \\
\hline Traditional & 3 & 4 & 7 & 16 \\
Non-Traditional & 3 & 5 & 7 & 16 \\
\hline
\end{tabular}


Table 3

Partial Correlations between Dependent Variables for Mother-Father Pairs with Child Sex Controlled $(N=15)$

\begin{tabular}{|c|c|c|c|c|c|c|}
\hline \multirow[t]{3}{*}{ DVs for Dads } & \multicolumn{6}{|c|}{ DVs for Moms } \\
\hline & \multicolumn{2}{|c|}{ Likelihood of providing } & \multicolumn{2}{|c|}{ Recently provided } & \multicolumn{2}{|c|}{ Feedback to play with } \\
\hline & Masculine & Feminine & Masculine & Feminine & Masculine & Feminine \\
\hline $\begin{array}{l}\text { Likelihood } \\
\text { masc }\end{array}$ & .36 & .21 & -.39 & .38 & .19 & .11 \\
\hline $\begin{array}{l}\text { Likelihood } \\
\qquad \text { fem }\end{array}$ & .49 & .15 & .10 & .36 & .07 & -.23 \\
\hline Recent masc & .07 & -.40 & $.94^{* *}$ & -.49 & -.21 & $-.63^{*}$ \\
\hline Recent fem & .05 & .13 & -01 & $.73^{* *}$ & -.23 & -.21 \\
\hline $\begin{array}{c}\text { Feedback } \\
\text { masc }\end{array}$ & .16 & -.21 & .04 & .09 & .31 & .02 \\
\hline $\begin{array}{l}\text { Feedback } \\
\text { fem }\end{array}$ & -.06 & -.22 & .16 & .05 & .24 & -.02 \\
\hline
\end{tabular}


Table 4

Partial Correlations for Dependent Variables of Fathers with Child Sex Controlled $(N=15)$

\begin{tabular}{|c|c|c|c|c|c|c|}
\hline DVs & 1 & 2 & 3 & 4 & 5 & 6 \\
\hline $\begin{array}{l}\text { 1. Masculine toys recently } \\
\text { provided for the child }\end{array}$ & -- & & & & & \\
\hline $\begin{array}{l}\text { 2. Feminine toys recently } \\
\text { provided for the child }\end{array}$ & -.31 & -- & & & & \\
\hline $\begin{array}{l}\text { 3. Likelihood of providing } \\
\text { masculine toys in the } f\end{array}$ & $.66^{* *}$ & -.28 & -- & & & \\
\hline $\begin{array}{l}\text { 4. Likelihood of providing } \\
\text { feminine toys in the fut }\end{array}$ & -.45 & $.57^{*}$ & -.17 & -- & & \\
\hline $\begin{array}{l}\text { 5. Feedback for play with } \\
\text { masculine toys }\end{array}$ & .25 & $-.57^{*}$ & $.56^{*}$ & -.24 & -- & \\
\hline $\begin{array}{l}\text { 6. Feedback for play with } \\
\text { feminine toys }\end{array}$ & -.50 & .21 & -.33 & $.62^{*}$ & .23 & -- \\
\hline
\end{tabular}


Table 5

Partial Correlations for Dependent Variables of Mothers with Child Sex Controlled $(N=46)$

\begin{tabular}{|c|c|c|c|c|c|c|}
\hline DVs & 1 & 2 & 3 & 4 & 5 & 6 \\
\hline $\begin{array}{l}\text { 1. Masculine toys recently } \\
\text { provided for the child }\end{array}$ & -- & & & & & \\
\hline $\begin{array}{l}\text { 2. Feminine toys recently } \\
\text { provided for the child }\end{array}$ & -.17 & -- & & & & \\
\hline $\begin{array}{l}\text { 3. Likelihood of providing } \\
\text { masculine toys in the } \mathrm{fu}\end{array}$ & .16 & -.13 & -- & & & \\
\hline $\begin{array}{l}\text { 4. Likelihood of providing } \\
\text { feminine toys in the futc }\end{array}$ & .05 & $.40^{* *}$ & .21 & -- & & \\
\hline $\begin{array}{l}\text { 5. Feedback for play with } \\
\text { masculine toys }\end{array}$ & .21 & .09 & $.49^{* *}$ & .21 & -- & \\
\hline $\begin{array}{l}\text { 6. Feedback for play with } \\
\text { feminine toys }\end{array}$ & -.13 & $.35^{\star}$ & -.16 & $.62^{* *}$ & .27 & -- \\
\hline
\end{tabular}


Table 6

Frequency of Toys Recently Provided Divided by Parent and Child Sex

\begin{tabular}{|c|c|c|c|c|c|}
\hline \multirow[t]{2}{*}{ Toys } & \multirow{2}{*}{$\begin{array}{l}\text { Gender- } \\
\text { typing }^{a}\end{array}$} & \multicolumn{2}{|c|}{ Mother } & \multicolumn{2}{|c|}{ Father } \\
\hline & & Son & Daughter & Son & Daughter \\
\hline $\mathrm{ABCs}$ and $123 \mathrm{~s}$ & $\mathrm{~N}$ & & 1 & & \\
\hline Aqua Doodle & $\mathrm{N}$ & & 1 & & \\
\hline Astronomy globe & $\mathrm{N}$ & & 1 & & 1 \\
\hline Baby Carriage & $\mathrm{F}$ & & 1 & & \\
\hline Baby doll & $\mathrm{F}$ & & 5 & & 4 \\
\hline Baby Einstein DVD & $\mathrm{N}$ & & 1 & & \\
\hline Ball popper & $\mathrm{N}$ & 1 & 2 & & \\
\hline Balls & $\mathrm{N}$ & 5 & 2 & 4 & 2 \\
\hline Band-aids & $\mathrm{N}$ & & & & 1 \\
\hline Banjo & $\mathrm{N}$ & 1 & & & \\
\hline Barbie Fairytopia & $\mathrm{F}$ & & 1 & & \\
\hline Barn & $\mathrm{N}$ & & 1 & & \\
\hline Barney DVD & $\mathrm{N}$ & 1 & & & \\
\hline Baseball & M & & & 1 & \\
\hline Basketball & M & 2 & & 1 & \\
\hline Basketball hoop & M & 1 & & 1 & \\
\hline Bath time toys & $\mathrm{N}$ & 1 & 3 & 1 & 2 \\
\hline
\end{tabular}


(Table 6 continued)

\begin{tabular}{|c|c|c|c|c|c|}
\hline \multirow[t]{2}{*}{ Toys } & \multirow{2}{*}{$\begin{array}{l}\text { Gender- } \\
\text { typing }^{\text {a }}\end{array}$} & \multicolumn{2}{|c|}{ Mother } & \multicolumn{2}{|c|}{ Father } \\
\hline & & Son & Daughter & Son & Daughter \\
\hline Batman & $\mathrm{M}$ & 1 & & & \\
\hline Bear in the Big Blue House & $\mathrm{N}$ & & & & \\
\hline DVD & & & & & 1 \\
\hline Bicycle & $\mathrm{N}$ & & 1 & & 1 \\
\hline Big Wheel & $\mathrm{N}$ & & 1 & & 1 \\
\hline Blanket & $\mathrm{N}$ & & & 1 & \\
\hline Blues Clues Blue Talks Toy & $\mathrm{N}$ & 2 & & & \\
\hline Blue's Clues letter finder & $\mathrm{N}$ & & 1 & & \\
\hline Bob the Builder doll & M & 1 & & & \\
\hline Bob the Builder DVD & M & 1 & & & \\
\hline Books & $\mathrm{N}$ & 6 & 17 & 1 & 2 \\
\hline Bowling set & $\mathrm{N}$ & & 1 & & \\
\hline Broom & $\mathrm{F}$ & & 1 & & \\
\hline Bubbles & $\mathrm{N}$ & & 1 & & \\
\hline Building blocks & $\mathrm{N}$ & 8 & 3 & 1 & \\
\hline Building table & M & & 1 & & \\
\hline Bulldozer & M & & & & 1 \\
\hline Bus & $\mathrm{N}$ & & 1 & & \\
\hline Cabbage Patch Kid & $\mathrm{F}$ & 1 & 5 & & 1 \\
\hline
\end{tabular}


(Table 6 continued)

\begin{tabular}{|c|c|c|c|c|c|}
\hline \multirow[t]{2}{*}{ Toys } & \multirow{2}{*}{$\begin{array}{l}\text { Gender- } \\
\text { typing }\end{array}$} & \multicolumn{2}{|c|}{ Mother } & \multicolumn{2}{|c|}{ Father } \\
\hline & & Son & Daughter & Son & Daughter \\
\hline Camping set & M & 1 & & 1 & \\
\hline Car garage & M & 2 & & 1 & \\
\hline Car wash & M & 1 & & 1 & \\
\hline Care Bears & $\mathrm{F}$ & & 2 & & \\
\hline Cars & M & 8 & 2 & 1 & 1 \\
\hline Cartoon DVDs & $\mathrm{N}$ & 1 & & & \\
\hline CD Player & $\mathrm{N}$ & 1 & 1 & & \\
\hline CDs & $\mathrm{N}$ & & & 1 & \\
\hline Cell phone & $\mathrm{F}$ & & 2 & & \\
\hline Chair & $\mathrm{N}$ & 1 & 1 & 1 & \\
\hline Chalkboard easel & $\mathrm{N}$ & & 1 & & 1 \\
\hline Clifford the Big Red Dog riding & $\mathrm{N}$ & & & & \\
\hline toy & & 1 & & & \\
\hline Coloring book & $\mathrm{N}$ & 2 & 4 & 1 & \\
\hline Construction set & M & & 1 & & \\
\hline Crayons & $\mathrm{N}$ & 3 & 4 & 2 & \\
\hline Dance mat & $\mathrm{N}$ & & & 1 & \\
\hline Dancing Dora the Explorer & $\mathrm{F}$ & & 1 & & \\
\hline Dinosaur & M & 1 & & 1 & \\
\hline
\end{tabular}


(Table 6 continued)

\begin{tabular}{|c|c|c|c|c|c|}
\hline \multirow[t]{2}{*}{ Toys } & \multirow{2}{*}{$\begin{array}{l}\text { Gender- } \\
\text { typing }^{a}\end{array}$} & \multicolumn{2}{|c|}{ Mother } & \multicolumn{2}{|c|}{ Father } \\
\hline & & Son & Daughter & Son & Daughter \\
\hline Disney Princess Tent & $\mathrm{F}$ & & 1 & & \\
\hline Disney Princess toy & $\mathrm{F}$ & & 2 & & 1 \\
\hline Doctor Elmo & M & 1 & 2 & & 1 \\
\hline Doll house & $\mathrm{F}$ & & 1 & & \\
\hline Doodle Pro & $\mathrm{N}$ & & 2 & & \\
\hline Door play set & $\mathrm{N}$ & & 1 & & 1 \\
\hline Dora the Explorer books & $\mathrm{F}$ & & & & 1 \\
\hline Dora the Explorer Couch & $F$ & & 2 & & 1 \\
\hline Dora the Explorer doll & $\mathrm{F}$ & & & & 1 \\
\hline Dora the Explorer DVD & $\mathrm{F}$ & & & & 1 \\
\hline Dress-up clothes & $\mathrm{F}$ & & 3 & & 1 \\
\hline Drum & $\mathrm{N}$ & 2 & 2 & & \\
\hline Dump truck & M & & 1 & & \\
\hline DVDs & $\mathrm{N}$ & & & 1 & \\
\hline Egg shaker & $\mathrm{N}$ & 1 & & 1 & \\
\hline Elmo doll & $\mathrm{N}$ & 2 & 3 & & 2 \\
\hline Elmo musical toy & $\mathrm{N}$ & & 2 & & 1 \\
\hline Elmo stickers & $\mathrm{N}$ & & 1 & & \\
\hline Ernie doll & $\mathrm{N}$ & & 1 & & \\
\hline
\end{tabular}


(Table 6 continued)

\begin{tabular}{|c|c|c|c|c|c|}
\hline \multirow[t]{2}{*}{ Toys } & \multirow{2}{*}{$\begin{array}{l}\text { Gender- } \\
\text { typing }^{a}\end{array}$} & \multicolumn{2}{|c|}{ Mother } & \multicolumn{2}{|c|}{ Father } \\
\hline & & Son & Daughter & Son & Daughter \\
\hline Etch-a-Sketch & $\mathrm{N}$ & & 1 & & \\
\hline Farm & $\mathrm{N}$ & 2 & & 1 & \\
\hline Finding Nemo Ball & $\mathrm{N}$ & & 1 & & \\
\hline Finger paints & $\mathrm{N}$ & 1 & 1 & & 1 \\
\hline Fire truck & M & 2 & & & \\
\hline Fish tank & $\mathrm{N}$ & 1 & & 1 & \\
\hline Football & M & 1 & 1 & & 1 \\
\hline GI Joe doll & M & & & 1 & \\
\hline Golf balls & M & 1 & & 1 & \\
\hline Gun & M & 1 & & & \\
\hline Hair clips & $\mathrm{F}$ & & 1 & & \\
\hline Hammer & M & & 1 & & \\
\hline Harmonica & $\mathrm{N}$ & & 1 & & \\
\hline Helicopter & M & 1 & & & \\
\hline Hockey set & M & 1 & & & \\
\hline Inflatable play land & $\mathrm{N}$ & & 1 & & 1 \\
\hline Instruments & $\mathrm{N}$ & 1 & 1 & 1 & 1 \\
\hline Jack in the Box & $\mathrm{N}$ & & & 1 & \\
\hline JoJo's Circus doll & $\mathrm{F}$ & & 1 & & 1 \\
\hline
\end{tabular}


(Table 6 continued)

\begin{tabular}{|c|c|c|c|c|c|}
\hline \multirow[t]{2}{*}{ Toys } & \multirow{2}{*}{$\begin{array}{l}\text { Gender- } \\
\text { typing }\end{array}$} & \multicolumn{2}{|c|}{ Mother } & \multicolumn{2}{|c|}{ Father } \\
\hline & & Son & Daughter & Son & Daughter \\
\hline JoJo's Circus figurine & $\mathrm{F}$ & & 1 & & \\
\hline Keys & $\mathrm{N}$ & 1 & & & \\
\hline Kitchen & $\mathrm{F}$ & 1 & 4 & & 1 \\
\hline Lawn mower & M & 1 & & & \\
\hline Leap Frog learning toy & $\mathrm{N}$ & 5 & 6 & 1 & 3 \\
\hline Leap frog train & M & 2 & & 1 & \\
\hline Leap Pad books & $\mathrm{N}$ & 4 & 3 & 1 & \\
\hline Leap Pad Learning Table & N & 1 & 2 & & \\
\hline Legos & M & 1 & 1 & & \\
\hline Little People people & $\mathrm{N}$ & 1 & 1 & & 1 \\
\hline Little People playground set & $\mathrm{N}$ & & 1 & & \\
\hline Little Touch Leap Pad & $\mathrm{N}$ & 1 & & & \\
\hline Magnadoodle & $\mathrm{N}$ & 2 & & & \\
\hline Magnetic letters & N & & 3 & & 1 \\
\hline Markers & $\mathrm{N}$ & 2 & & & \\
\hline Medical Kit & $\mathrm{N}$ & & 1 & & \\
\hline Megablocks & M & 2 & 3 & 1 & 2 \\
\hline Megablocks Castle & $\mathrm{M}$ & 1 & & & \\
\hline Megablocks truck & M & 1 & & 1 & 1 \\
\hline
\end{tabular}


(Table 6 continued)

\begin{tabular}{|c|c|c|c|c|c|}
\hline \multirow[t]{2}{*}{ Toys } & \multirow{2}{*}{$\begin{array}{l}\text { Gender- } \\
\text { typing }\end{array}$} & \multicolumn{2}{|c|}{ Mother } & \multicolumn{2}{|c|}{ Father } \\
\hline & & Son & Daughter & Son & Daughter \\
\hline Microphone & $\mathrm{N}$ & 1 & 1 & & \\
\hline Motorboat & M & & 1 & & \\
\hline Motorcycles & M & 1 & & & \\
\hline Motorized ball maze & $\mathrm{N}$ & & 1 & & 1 \\
\hline Mr. Potato Head Silly suitcase & $\mathrm{N}$ & 1 & & & \\
\hline Musical hand puppet & $\mathrm{N}$ & & 1 & & \\
\hline My Little Pony pony & $\mathrm{F}$ & & 1 & & 1 \\
\hline My Twinn custom doll & $\mathrm{F}$ & 1 & & & \\
\hline Ninja Turtles ball & M & 1 & & & \\
\hline Noah's Ark & $\mathrm{N}$ & 1 & 1 & & \\
\hline Number blocks & $\mathrm{N}$ & 1 & & & \\
\hline Number magnets & $\mathrm{N}$ & & 1 & & 1 \\
\hline Phone & $\mathrm{N}$ & 1 & & 1 & 1 \\
\hline Piano & $\mathrm{N}$ & 4 & 3 & 1 & 1 \\
\hline Play dishes \& food & $\mathrm{F}$ & & 3 & & \\
\hline Play-Doh & $\mathrm{N}$ & 1 & 1 & 1 & 1 \\
\hline Playhouse & $\mathrm{N}$ & & 1 & & \\
\hline Playskool Weebles & $\mathrm{N}$ & & 2 & & \\
\hline Police car & M & 1 & & & \\
\hline
\end{tabular}


(Table 6 continued)

\begin{tabular}{|c|c|c|c|c|c|}
\hline \multirow[t]{2}{*}{ Toys } & \multirow{2}{*}{$\begin{array}{l}\text { Gender- } \\
\text { typing }^{a}\end{array}$} & \multicolumn{2}{|c|}{ Mother } & \multicolumn{2}{|c|}{ Father } \\
\hline & & Son & Daughter & Son & Daughter \\
\hline Pool/sand toys & $\mathrm{N}$ & 1 & 1 & & \\
\hline Power Wheels & M & 1 & 2 & & 1 \\
\hline Pull horse & $\mathrm{N}$ & 1 & & & \\
\hline Punching bag & M & 1 & & & \\
\hline Puzzles & $\mathrm{N}$ & 1 & 4 & 2 & 2 \\
\hline Race car & M & 1 & & & \\
\hline Race track & M & 1 & & 1 & \\
\hline Read-along DVD & $\mathrm{N}$ & 1 & & & \\
\hline Remote control cars & M & 3 & 1 & 2 & \\
\hline Ride-in car & M & 1 & & & \\
\hline Ring Toss & $\mathrm{N}$ & 1 & & & \\
\hline Robots & M & 1 & & & \\
\hline Rocker & $\mathrm{N}$ & 1 & & 1 & \\
\hline Rocking horse & N & 3 & & 1 & 1 \\
\hline Rubber duck & $\mathrm{N}$ & & 1 & & 1 \\
\hline School bus & $\mathrm{N}$ & 1 & 1 & & \\
\hline School house & $\mathrm{N}$ & 1 & 1 & & \\
\hline Sesame Street giggle box & $\mathrm{N}$ & & 1 & & \\
\hline Shape sorter & $\mathrm{N}$ & 3 & 1 & & 1 \\
\hline
\end{tabular}


(Table 6 continued)

\begin{tabular}{|c|c|c|c|c|c|}
\hline \multirow[t]{2}{*}{ Toys } & \multirow{2}{*}{$\begin{array}{l}\text { Gender- } \\
\text { typing }^{\mathrm{a}}\end{array}$} & \multicolumn{2}{|c|}{ Mother } & \multicolumn{2}{|c|}{ Father } \\
\hline & & Son & Daughter & Son & Daughter \\
\hline Shopping cart & $\mathrm{F}$ & 2 & 2 & 1 & \\
\hline Singing Eeyore & $\mathrm{N}$ & 1 & & & \\
\hline Sit n' Spin & $\mathrm{N}$ & 2 & 1 & & \\
\hline Sled & $\mathrm{N}$ & 2 & & & \\
\hline Slide & $\mathrm{N}$ & & 1 & & \\
\hline Soccer ball & M & 1 & & & \\
\hline Speak n' Say & $\mathrm{N}$ & 2 & & & \\
\hline Splash Bomb water toy & M & & 1 & & 1 \\
\hline Sponge Bob ball & M & & 1 & & \\
\hline Sponge Bob bath set & M & & 1 & & \\
\hline Sponge Bob doll & M & 1 & 2 & & 1 \\
\hline Sponge Bob DVD & M & & 1 & & \\
\hline Sports balls & M & 1 & & 1 & \\
\hline Stacking Blocks & M & & 1 & & \\
\hline Stacking cups & $\mathrm{N}$ & 1 & & & \\
\hline Stacking rings & $\mathrm{N}$ & 1 & & & \\
\hline Stuffed animals & $\mathrm{N}$ & 4 & 2 & & 1 \\
\hline Swing Set & $\mathrm{N}$ & & 1 & & 1 \\
\hline Table and chair & $\mathrm{N}$ & & 1 & & \\
\hline
\end{tabular}


(Table 6 continued)

\begin{tabular}{|c|c|c|c|c|c|}
\hline \multirow[t]{2}{*}{ Toys } & \multirow{2}{*}{$\begin{array}{l}\text { Gender- } \\
\text { typing }^{\text {a }}\end{array}$} & \multicolumn{2}{|c|}{ Mother } & \multicolumn{2}{|c|}{ Father } \\
\hline & & Son & Daughter & Son & Daughter \\
\hline Talkin' Tigger' & $\mathrm{N}$ & 2 & & & \\
\hline Talking grill & M & 1 & & & \\
\hline Tambourine & $\mathrm{N}$ & & 1 & & \\
\hline Tea set & $\mathrm{F}$ & & 4 & & 1 \\
\hline Teddy Bear & $\mathrm{F}$ & 1 & 2 & & \\
\hline Tee ball set & M & 1 & & & \\
\hline Thomas the Train book & M & 1 & & & \\
\hline Thomas the Train whistle & M & 1 & & & \\
\hline Tool set & M & 1 & & 1 & \\
\hline Train set & M & 3 & & 1 & \\
\hline Tree house & M & & 1 & & 1 \\
\hline Tricycle & $\mathrm{N}$ & 1 & 2 & & \\
\hline Trucks & M & 6 & 1 & 1 & 2 \\
\hline Tunnels & M & 2 & & & \\
\hline Vacuum cleaner & $\mathrm{F}$ & 1 & 4 & & 1 \\
\hline Vanity set & $\mathrm{F}$ & & 2 & & \\
\hline Veggietales DVD & $\mathrm{N}$ & & & 1 & \\
\hline Wagon & M & 1 & & & \\
\hline Walkie Talkies & M & & & & 1 \\
\hline
\end{tabular}


(Table 6 continued)

\begin{tabular}{lccccc}
\hline \multirow{2}{*}{ Toys } & $\begin{array}{c}\text { Gender- } \\
\text { typing }\end{array}$ & \multicolumn{2}{c}{ Mother } & \multicolumn{2}{c}{ Father } \\
\cline { 3 - 6 } & & Son & Daughter & Son & Daughter \\
\hline Weebles people & $\mathrm{N}$ & 2 & & & \\
Wheelbarrow & $\mathrm{M}$ & 1 & & & \\
Wiggles DVD & $\mathrm{N}$ & 2 & & 1 & \\
Winnie the Pooh & $\mathrm{N}$ & 1 & & 1 & \\
Workbench & $\mathrm{M}$ & 2 & & & \\
Xylophone & $\mathrm{N}$ & 1 & 1 & 1 & 2 \\
Zoo set & $\mathrm{N}$ & & 3 & & \\
\end{tabular}

Note. Some toys listed as gender-neutral in this table were rated as either masculine (e.g., Ninja Turtles sled) or feminine (e.g., pink ball). Rather than listing every single toy provided, toys in similar categories (e.g., balls, regardless of color or character endorsement) were listed together.

${ }^{\mathrm{a}}$ Gender-typing was determined using the gender category of the toy assigned in Campenni (1999). When a toy was listed that was not included in Campenni, the toy was rated by the researcher, another graduate student, and two undergraduate students. 
Table 7

Two-Way Analyses of Variance for Gender-Typed Toys Recently Provided by Mothers and Fathers

\begin{tabular}{|c|c|c|c|c|}
\hline Variable and source & $F$ & $d f$ & $p$ & power \\
\hline \multicolumn{5}{|l|}{ Masculine toys from mothers } \\
\hline Child Sex & 21.25 & 1,42 & .00 & .99 \\
\hline Gender-Role Orientation & .01 & 1,42 & .92 & .05 \\
\hline Child Sex x Gender-Role Orientation & .00 & 1,42 & .96 & .05 \\
\hline \multicolumn{5}{|l|}{ Feminine toys from mothers } \\
\hline Child Sex & 24.13 & 1,42 & .00 & 1.00 \\
\hline Gender-Role Orientation & 1.65 & 1,42 & .21 & .24 \\
\hline Child Sex x Gender-Role Orientation & .16 & 1,42 & .69 & .07 \\
\hline \multicolumn{5}{|l|}{ Masculine toys from fathers } \\
\hline Child Sex & 4.09 & 1,11 & .07 & .46 \\
\hline Gender-Role Orientation & .13 & 1,11 & .73 & .06 \\
\hline Child Sex x Gender-Role Orientation & .58 & 1,11 & .46 & .11 \\
\hline \multicolumn{5}{|l|}{ Feminine toys from fathers } \\
\hline Child Sex & 7.13 & 1,11 & .02 & .68 \\
\hline Gender-Role Orientation & 5.03 & 1,11 & .05 & .53 \\
\hline Child Sex x Gender-Role Orientation & 1.05 & 1,11 & .33 & .16 \\
\hline
\end{tabular}


Table 8

Means and Standard Deviations for the Proportions of Gender-Typed Toys Provided

Divided by Child Sex $(N=61)$

\begin{tabular}{ccccc}
\hline DV & \multicolumn{2}{c}{ Mothers $(\mathrm{n}=46)$} & \multicolumn{2}{c}{ Fathers $(\mathrm{n}=15)$} \\
\cline { 2 - 5 } & Sons & Daughters & Sons & Daughters \\
& $(\mathrm{n}=23)^{\star *}$ & $(\mathrm{n}=23)^{* *}$ & $(\mathrm{n}=6)+$ & $(\mathrm{n}=9)^{*}$ \\
\hline Masculine-typed & $45.49 \%(4.98)$ & $13.04 \%(4.98)$ & $45.00 \%$ & $17.57 \%(8.61)$ \\
toys provided & & & $(10.48)$ & \\
Feminine-typed & $6.47 \%(3.36)$ & $29.84 \%(3.36)$ & $4.44 \%(5.64)$ & $23.92 \%(4.63)$ \\
toys provided & & & & \\
\hline$+p=.07,{ }^{*} p<.05,{ }^{* *} p<.01$. & & & \\
\end{tabular}


Table 9

Means and Standard Deviations for the Number of Gender-Typed Toys Provided Divided by Gender-Role Orientation ( $N=61)$

\begin{tabular}{ccccc}
\hline \multirow{2}{*}{ DV } & \multicolumn{2}{c}{ Mothers $(\mathrm{n}=46)$} & \multicolumn{2}{c}{ Fathers $(\mathrm{n}=15)$} \\
\cline { 2 - 5 } & $\begin{array}{c}\text { Traditional } \\
(\mathrm{n}=14)\end{array}$ & $\begin{array}{c}\text { Nontraditional } \\
(\mathrm{n}=32)\end{array}$ & $\begin{array}{c}\text { Traditional } \\
(\mathrm{n}=7)\end{array}$ & $\begin{array}{c}\text { Nontraditional } \\
(\mathrm{n}=8)\end{array}$ \\
\hline Masculine-typed & $28.92 \%$ & $29.61 \%$ & $28.89 \%$ & $33.68 \%$ \\
toys provided & $(5.87)$ & $(3.88)$ & $(9.80)$ & $(9.37)$ \\
Feminine-typed toys & $21.21 \%$ & $15.10 \%$ & $22.36 \%$ & $6.00 \%$ \\
provided & $(3.97)$ & $(2.63)$ & $(5.27)_{a}$ & $(5.04)_{a}$
\end{tabular}

Note. Means with the same subscript differ significantly at $p<.05$. 
Table 10

Two-Way Analyses of Variance for the Likelihood of Mothers and Fathers Providing Gender-Typed Toys in the Future

\begin{tabular}{|c|c|c|c|c|}
\hline Variable and source & $F$ & $d f$ & $p$ & power \\
\hline \multicolumn{5}{|l|}{ Masculine toys from mothers } \\
\hline Child Sex & 60.99 & 1,42 & .00 & 1.00 \\
\hline Gender-Role Orientation & 1.68 & 1,42 & .20 & .24 \\
\hline Child Sex x Gender-Role Orientation & 2.44 & 1,42 & .13 & .33 \\
\hline \multicolumn{5}{|l|}{ Feminine toys from mothers } \\
\hline Child Sex & 29.41 & 1,41 & .00 & 1.00 \\
\hline Gender-Role Orientation & .07 & 1,41 & .79 & .06 \\
\hline Child Sex x Gender-Role Orientation & 3.49 & 1,41 & .07 & .45 \\
\hline \multicolumn{5}{|l|}{ Masculine toys from fathers } \\
\hline Child Sex & 4.08 & 1,11 & .07 & .45 \\
\hline Gender-Role Orientation & .16 & 1,11 & .69 & .07 \\
\hline Child Sex x Gender-Role Orientation & .99 & 1,11 & .34 & .15 \\
\hline \multicolumn{5}{|l|}{ Feminine toys from fathers } \\
\hline Child Sex & 9.46 & 1,11 & .01 & .80 \\
\hline Gender-Role Orientation & 2.81 & 1,11 & .12 & .33 \\
\hline Child Sex x Gender-Role Orientation & .32 & 1,11 & .58 & .08 \\
\hline
\end{tabular}


Table 11

Means and Standard Deviations for the Likelihood of Providing Gender-Typed Toys in the Future Divided by Child Sex $(N=61)$

\begin{tabular}{lcccc}
\hline \multirow{2}{*}{ DV } & \multicolumn{2}{c}{ Mothers } & \multicolumn{2}{c}{ Fathers } \\
\cline { 2 - 5 } & Sons $^{* *}$ & Daughters & Sons ${ }^{* *}$ & Daughters \\
& & & & \\
\hline Masculine-typed toys & $3.90(.19)$ & $1.83(.19)$ & $3.55(.42)$ & $2.46(.34)$ \\
Feminine-typed toys & $2.06(.16)$ & $3.32(.17)$ & $1.88(.34)$ & $3.24(.28)$ \\
\hline
\end{tabular}

$+p<.07,{ }^{*} p<.05,{ }^{* *} p<.01$. 
Table 12

Two-Way Analyses of Variance for Feedback Provided to Children's Play with GenderTyped Toys

\begin{tabular}{|c|c|c|c|c|}
\hline Variable and source & $F$ & $d f$ & $p$ & power \\
\hline \multicolumn{5}{|l|}{ Mothers' feedback to masculine toys } \\
\hline Child Sex & 7.32 & 1,41 & .01 & .75 \\
\hline Gender-Role Orientation & .02 & 1,41 & .90 & .05 \\
\hline Child Sex x Gender-Role Orientation & .24 & 1,41 & .63 & .08 \\
\hline \multicolumn{5}{|l|}{ Mothers' feedback to feminine toys } \\
\hline Child Sex & 35.07 & 1,41 & .00 & 1.00 \\
\hline Gender-Role Orientation & 1.79 & 1,41 & .19 & .26 \\
\hline Child Sex x Gender-Role Orientation & .76 & 1,41 & 39 & .14 \\
\hline \multicolumn{5}{|l|}{ Fathers' feedback to masculine toys } \\
\hline Child Sex & .27 & 1,11 & .61 & .08 \\
\hline Gender-Role Orientation & .30 & 1,11 & .60 & .08 \\
\hline Child Sex x Gender-Role Orientation & .58 & 1,11 & .46 & .11 \\
\hline \multicolumn{5}{|l|}{ Fathers' feedback to feminine toys } \\
\hline Child Sex & 5.23 & 1,11 & .04 & .55 \\
\hline Gender-Role Orientation & 1.46 & 1,11 & .25 & .20 \\
\hline Child Sex $\times$ Gender-Role Orientation & .27 & 1,11 & .61 & .08 \\
\hline
\end{tabular}


Table 13

Means and Standard Deviations for Feedback to Play with Gender-Typed Toys Divided by Child Sex $(N=61)$

\begin{tabular}{lcccc}
\hline \multirow{2}{*}{ DV } & \multicolumn{2}{c}{ Mothers } & \multicolumn{2}{c}{ Fathers } \\
\cline { 2 - 5 } & Sons $^{* *}$ & Daughters** & Sons & Daughters* \\
\hline Masculine-typed toys & $4.16(.22)$ & $3.32(.22)$ & $3.79(.36)$ & $3.55(.30)$ \\
Feminine-typed toys & $2.75(.18)$ & $4.26(.18)$ & $2.36(.46)$ & $3.71(.37)$ \\
\hline
\end{tabular}

Note. Scale of feedback ranged from 1 (Extremely likely to discourage play) to 3 (Equally likely to encourage or discourage play) to 5 (Extremely likely to encourage play). ${ }^{*} p<.05,{ }^{* *} p<.01$. 
Table 14

Partial Correlations for Toddler Temperament Subscales and Dependent Variables with Child Sex Controlled for $(N=43)$

\begin{tabular}{|c|c|c|c|c|c|c|}
\hline \multirow[t]{2}{*}{ Subscales } & \multicolumn{2}{|c|}{ Recently provided toys } & \multicolumn{2}{|c|}{ Likelihood of providing } & \multicolumn{2}{|c|}{ Feedback to play } \\
\hline & Masculine & Feminine & Masculine & Feminine & Masculine & Feminine \\
\hline Activity & -.07 & .21 & .13 & $.34^{*}$ & .05 & .11 \\
\hline Rhythmicity & .08 & .15 & .27 & .17 & .21 & .02 \\
\hline Approach & -.17 & .13 & -.08 & .06 & -.15 & .16 \\
\hline Adaptability & $-.30^{*}$ & .02 & -.12 & 17 & -.02 & $.36^{*}$ \\
\hline Intensity & .00 & .06 & .16 & 12 & .29 & 14 \\
\hline Mood & -.13 & .09 & .05 & .04 & -.17 & .01 \\
\hline Persistence & -.03 & -.12 & -.08 & .00 & -.03 & -.13 \\
\hline Distractibility & .06 & $.36^{*}$ & $.32^{*}$ & $.40^{* *}$ & .06 & -.01 \\
\hline Threshold & -.03 & $.37^{*}$ & -.14 & 11 & .20 & $.36^{*}$ \\
\hline
\end{tabular}

Note. All Toddler Temperament Scales were completed by the mother. All dependent variables are from mothers only.

${ }^{*} p<.05 .{ }^{* *} p<.01$ 
Table 15

Intercorrelations for Subscales of the Toddler Temperament Scale $(N=43)$

\begin{tabular}{lccccccccc}
\hline Measures & 1 & 2 & 3 & 4 & 5 & 6 & 7 & 8 & 9 \\
\hline 1. Activity & -- & & & & & & & \\
2. Rhythmicity & $.31^{*}$ & -- & & & & & & & \\
3. Approach & -.09 & $.35^{*}$ & -- & & & & & \\
4. Adaptability & .26 & $.40^{* *}$ & $.40^{* *}$ & -- & & & & \\
5. Intensity & $.30^{*}$ & .23 & .08 & $.41^{* *}$ & -- & & & \\
6. Mood & .28 & $.58^{* *}$ & $.61^{* *}$ & $.56^{* *}$ & .27 & -- & & \\
7. Persist. & .02 & .12 & -.04 & -.07 & -.21 & -.14 & -- & & \\
8. Distract. & .29 & .13 & .12 & -.08 & -.18 & .12 & .07 & -- & \\
9. Threshold & $.34^{*}$ & -.03 & $.31^{*}$ & .17 & .23 & .15 & -.03 & .26 & -- \\
\hline
\end{tabular}

${ }^{*} p<.05 .{ }^{* *} p<.01$ 
Appendix A: Recruitment Letter

Relations Among Child Personality, Parent Personality, and Child Play Behavior Recruitment Letter

\section{Dear Parents,}

My name is Jenny Hartley and I am a graduate student in the Life-Span Developmental Psychology program at West Virginia University. I am conducting a study to examine how the personalities of parents and children are related to the play behavior of first-born toddlers. I am seeking mothers and fathers of first-born toddlers between the ages of 17 and 19 months who would be willing to participate in this study.

Participation in this study involves completing several questionnaires at home. The questionnaires will be mailed to your home and should take approximately 45-60 minutes to complete. These questionnaires measure your toddler's temperament and play behavior, and also collect information about you, your toddler, and your family. You will then return the questionnaires in a postage-paid envelope. All information that is obtained through the questionnaires will be kept strictly confidential; your names or other identifying information will not be used in any reports that are released from this study.

To thank you for your participation, your family will receive a $\$ 10$ gift certificate to Target. If you are a psychology student, you will have the option of receiving either the $\$ 10$ gift certificate to Target or extra credit in your psychology class. You participation is voluntary and you would be free to exit the study at any point with no consequences to you. If only one of you wish to participate, that is fine also.

If you are interested in participating in this study or would like more information, please contact me by phone at 293-2001 and leave a message, or by e-mail at jhartle1@mix.wvu.edu. You may receive a follow-up phone call from a research assistant if we don't hear from you.

Thank you for your time!

Sincerely,

Jennifer Hartley, B. A.

Version date: September 26, 2005 
Appendix B

\section{CONSENT AND INFORMATION FORM}

Relations Among Child Personality, Parent Personality, and Child Play Behavior

\section{Introduction}

I, , have been invited to participate in this research study which

has been explained to me by . This research is being conducted to fulfill the requirements for Jennifer K. Hartley's master's thesis in life-span developmental psychology in the Department of Psychology at West Virginia University, under the supervision of Dr. Katherine Karraker, Ph.D.

\section{Purposes of the Study}

The purpose of this study is to learn more about how a child's personality and his or her parents' personalities relate to the child's play behavior. The characteristics to be rated by participants include personality traits of the self and the child, and toy and play preferences of the child.

\section{Description of Procedures}

This study involves the completion of questionnaires, including a personality inventory, a child temperament inventory, and an inventory of the child's toy play behavior. A demographics questionnaire about each participant will be completed after the other questionnaires. This study will take approximately one hour for me to complete. I understand that I may see the questionnaires before signing this consent form and that I do not have to answer all the questions if I decide to participate. Approximately 100 families are expected to participate in this study.

\section{Risks and Discomforts}

There are no known or expected risks from participating in this study, except for any mild frustration that may be associated with the completion of the questionnaires. A referral list for counseling, for yourself or your child, is available upon request.

\section{Alternatives}

I understand that I do not have to participate in this study.

\section{Benefits}

I understand that this study is not expected to be of direct benefit to me, but the knowledge gained may be of benefit to others. 
The Relations Between Child Personality, Parent Personality, and Child Play Behavior

\section{Financial Considerations}

If you are not a psychology student, you will receive a $\$ 10$ gift certificate to Target. If you are a psychology student, you may receive either a $\$ 10$ gift certificate to Target or extra credit in your class.

\section{Contact Persons}

For more information about this research, I can contact Jennifer K. Hartley

(jhartle1@mix.wvu.edu), or her supervisor, Dr. Katherine Karraker (304-293-2001 ext 31625;

kkarrake@mail.wvu.edu). For information regarding my rights as a research subject, I may contact the Executive Secretary of the Institutional Review Board at 304-293-7073.

\section{Confidentiality}

I understand that any information about me obtained as a result of my participation in this research will be kept as confidential as legally possible. I understand that my research records and test results, just like hospital records, may be subpoenaed by court order or may be inspected by the study sponsor or federal regulatory authorities (including the FDA if applicable) without my additional consent. In any publications that result from this research, neither my name nor any information from which I might be identified will be published without my consent.

\section{Voluntary Participation}

Participation in this study is voluntary. I understand that I am free to withdraw my consent to participate in this study at any time and that such refusal to participate will not affect my future care. Refusal to participate or withdrawal will involve no penalty to me. I have been given the opportunity to ask questions about the research and I have received answers concerning areas I did not understand. In the event new information becomes available that may affect my willingness to participate in this study, this information will be given to me so that I may make an informed decision about my participation.

Upon signing this form, I will receive a copy.

I willingly consent to participate in this research.

Signature of Subject or Subject's Legal Representative

Signature of Investigator or Investigator's Representative
Page 2 of 2
Date

Time

Date

Time

initials

date 
Appendix C

Dear Parent,

Thank you very much for agreeing to participate in this study. Enclosed with this letter you will find a packet of questionnaires and forms for you and the child's other parent (if that person has also agreed to participate) to complete. There are two sets of all forms except the Toddler Temperament Questionnaire. The forms should only take about 45-60 minutes to complete. The first form you will find is the consent form for this study. Please read and sign one copy to return with the questionnaires; the second copy is for you to keep. The next questionnaire is the Toy/Play Questionnaire, which asks questions about your child's toy and play preferences. The next form is the Toddler Temperament Questionnaire. As there is only one copy of this questionnaire, I ask that the child's primary caregiver complete this form. This questionnaire asks questions about your child's behavior in various situations. The third form is the Adult Personality Inventory, which asks about how much you consider certain adjectives to describe yourself. The last form in this packet is the Demographics Questionnaire, which asks about you, your child, and your family. Please feel free to skip any question on any form that makes you feel uncomfortable.

Please complete all of the forms by yourself and to the best of your knowledge. Also enclosed with this packet are two return envelopes. Please return each set of forms, yours and the child's other parent's, separately.

Sincerely,

Jennifer Hartley, B.A.

Version date: July 12, 2005 
Appendix D

\title{
Get a $\$ 10$ gift certificate to Target! \\ By participating in a research project
}

Participants must be parents of first-born infants between the ages of 17 and 19 months.

Participation involves the completion of a few simple questionnaires.

\author{
If interested, please contact Jenny Hartley at \\ jhartle1@mix.wvu.edu or \\ leave a message for her at (304) 293-2001.
}




\section{Appendix E}

\section{Telephone Text}

Hello! , my name is and I am a research assistant/graduate student working with Dr. Katherine Karraker in the psychology department at West Virginia University. We are looking for parents of first-born infants between the ages of 17 and 19 months to participate in a master's thesis study. The study will examine the personalities of the child and parents, and how those personalities relate to the child's play behavior. Do you have a first-born child in this age range?

If you are willing to participate in this study, I will mail to you a packet of questionnaires for you and your partner (if your partner is also willing to participate) to complete and mail back in a postage-paid envelope. The questionnaires will include a personality inventory for each parent, one for the child, a toy/play inventory, and a demographics survey. The questionnaires should not take more than an hour to complete. All of the information that we obtain from you will be kept confidential, as your names or other identifying information will not be used in any reports that are released from this study. To thank you for your participation, we will send you a $\$ 10$ gift certificate to Target. Participation is entirely voluntary and you may refuse to answer any questions with no consequence to you.

If the parent agrees to participate: Great! Let me go ahead and verify your mailing address. Thank you very much for agreeing to participate in this study.

If the parent is not interested in participating: Thank you very much for your time and have a nice day. 


\section{Appendix F}

\section{Toy / Play Questionnaire}

1. What is your child's favorite color?

2. What is your child's favorite outfit?

3. What is your child's favorite toy?

4. What color is your child's room?

5. What is your child's favorite book?

6. What is your child's favorite television program?

7. Which toys (title and/or brand name) does your child play with most often?

8. When you play with your child, which toys (title and/or brand name) do you play with most often? 
9. Please provide the brand names and/or titles of the 10 toys that you most recently purchased for your child.

1.

2.

3.

4.

5.

6.

7.

8.

9.

10. 
Please rate the toys provided in the list below according to the scales for each of the following 5 questions.

11. If money were not a consideration, how likely would you be to provide each of the following toys for your child in the next 6 months?

\begin{tabular}{|c|c|c|c|c|}
\hline $\mathbf{1}$ & $\mathbf{2}$ & $\mathbf{3}$ & $\mathbf{4}$ & $\mathbf{5}$ \\
\hline $\begin{array}{c}\text { Extremely unlikely } \\
\text { (Would never or } \\
\text { almost never } \\
\text { provide this toy.) }\end{array}$ & $\begin{array}{c}\text { Somewhat unlikely } \\
\text { (Variable, but } \\
\text { probably would } \\
\text { not provide this } \\
\text { toy.) }\end{array}$ & $\begin{array}{c}\text { Equal } \\
\text { (Equally likely or } \\
\text { unlikely to } \\
\text { provide this toy.) }\end{array}$ & $\begin{array}{c}\text { Somewhat likely } \\
\text { (Variable, but } \\
\text { probably would } \\
\text { provide this toy.) }\end{array}$ & $\begin{array}{c}\text { Extremely likely } \\
\text { (Absolutely } \\
\text { would provide } \\
\text { this toy.) }\end{array}$ \\
\hline
\end{tabular}

\begin{tabular}{|l|l|}
\hline & Audio cassettes \\
\hline & Baby doll \\
\hline & Baby feeding set \\
\hline & Barbecue grill \\
\hline & Barbie \\
\hline & Batman \\
\hline & Batmobile \\
\hline & Bracelets \\
\hline & Cabbage Patch doll \\
\hline & Camera \\
\hline & Carpentry tool set \\
\hline & Cassette player \\
\hline & Catwoman \\
\hline & Chalkboard \\
\hline & Chime ball \\
\hline & Construction truck \\
\hline & Cowboy \\
\hline & Cradle \\
\hline & Doctor kit \\
\hline & Doll house \\
\hline & Doll house furniture \\
\hline & Dress-up clothes \\
\hline & Easel \\
\hline & Educational books \\
\hline & \\
\hline
\end{tabular}

\begin{tabular}{|l|l|}
\hline & Esmerelda doll \\
\hline & Female superhero \\
\hline & Finger paints \\
\hline & Fireman hat \\
\hline & Firetruck \\
\hline & Football gear \\
\hline & Garage and cars \\
\hline & Gas station and cars \\
\hline & Gl Joe \\
\hline & Globe \\
\hline & Godzilla \\
\hline & Hand puppet \\
\hline & Jewelry box \\
\hline & Kaleidoscope \\
\hline & Kitchen center \\
\hline & Magna-Doodle \\
\hline & Magnetic letters \\
\hline & Male superhero \\
\hline & Matchbox cars \\
\hline & Mickey Mouse \\
\hline & Minnie Mouse \\
\hline & Miss Piggy \\
\hline & Motorcycle \\
\hline & Ninja Warrior Set \\
\hline & \\
\hline
\end{tabular}

\begin{tabular}{|c|}
\hline Palace \\
\hline Piano \\
\hline Picture books \\
\hline Play Dough Factory \\
\hline Pocahontas doll \\
\hline $\begin{array}{l}\text { Police helmet and } \\
\text { vest }\end{array}$ \\
\hline Pots and pans \\
\hline Power Rangers \\
\hline Puzzles \\
\hline Race car \\
\hline Race track set \\
\hline Ring toss \\
\hline Rubber duck \\
\hline Snap-together beads \\
\hline Spiderman \\
\hline Stacking rings \\
\hline Stroller \\
\hline Tea set \\
\hline Toy soldiers \\
\hline Tub toys \\
\hline Vacuum cleaner \\
\hline Workbench and tools \\
\hline
\end{tabular}


12. How likely would you be to encourage your child if he or she began playing with each of the following toys?

\begin{tabular}{|c|c|c|c|c|}
\hline $\mathbf{1}$ & $\mathbf{2}$ & $\mathbf{3}$ & $\mathbf{4}$ & $\mathbf{5}$ \\
\hline $\begin{array}{c}\text { Not at all likely } \\
\text { (Would always } \\
\text { or almost always } \\
\text { discourage play } \\
\text { with this toy.) }\end{array}$ & $\begin{array}{c}\text { Somewhat } \\
\text { unlikely } \\
\text { (Variable, but } \\
\text { probably would } \\
\text { discourage play } \\
\text { with this toy.) }\end{array}$ & $\begin{array}{c}\text { Equal } \\
\text { (Equally likely to } \\
\text { encourage or } \\
\text { discourage play } \\
\text { with this toy.) }\end{array}$ & $\begin{array}{c}\text { Somewhat likely } \\
\text { (Variable, but } \\
\text { probably would } \\
\text { encourage play } \\
\text { with this toy.) }\end{array}$ & $\begin{array}{c}\text { Extremely likely } \\
\text { (Would always } \\
\text { or almost always } \\
\text { encourage play } \\
\text { with this toy.) }\end{array}$ \\
\hline
\end{tabular}

\begin{tabular}{|l|l|}
\hline & Audio cassettes \\
\hline & Baby doll \\
\hline & Baby feeding set \\
\hline & Barbecue grill \\
\hline & Barbie \\
\hline & Batman \\
\hline & Batmobile \\
\hline & Bracelets \\
\hline & Cabbage Patch doll \\
\hline & Camera \\
\hline & Carpentry tool set \\
\hline & Cassette player \\
\hline & Catwoman \\
\hline & Chalkboard \\
\hline & Chime ball \\
\hline & Construction truck \\
\hline & Cowboy \\
\hline & Cradle \\
\hline & Doctor kit \\
\hline & Doll house \\
\hline & Doll house furniture \\
\hline & Dress-up clothes \\
\hline & Easel \\
\hline & Educational books \\
\hline & \\
\hline
\end{tabular}

\begin{tabular}{|l|l|}
\hline & Esmerelda doll \\
\hline & Female superhero \\
\hline & Finger paints \\
\hline & Fireman hat \\
\hline & Firetruck \\
\hline & Football gear \\
\hline & Garage and cars \\
\hline & Gas station and cars \\
\hline & Gl Joe \\
\hline & Globe \\
\hline & Godzilla \\
\hline & Hand puppet \\
\hline & Jewelry box \\
\hline & Kaleidoscope \\
\hline & Kitchen center \\
\hline & Magna-Doodle \\
\hline & Magnetic letters \\
\hline & Male superhero \\
\hline & Matchbox cars \\
\hline & Mickey Mouse \\
\hline & Minnie Mouse \\
\hline & Miss Piggy \\
\hline & Motorcycle \\
\hline & Ninja Warrior Set \\
\hline & \\
\hline
\end{tabular}

\begin{tabular}{|l|l|}
\hline & Palace \\
\hline & Piano \\
\hline & Picture books \\
\hline & Play Dough Factory \\
\hline & Pocahontas doll \\
\hline & $\begin{array}{l}\text { Police helmet and } \\
\text { vest }\end{array}$ \\
\hline & Pots and pans \\
\hline & Power Rangers \\
\hline & Puzzles \\
\hline & Race car \\
\hline & Race track set \\
\hline & Ring toss \\
\hline & Rubber duck \\
\hline & Snap-together beads \\
\hline & Spiderman \\
\hline & Stacking rings \\
\hline & Stroller \\
\hline & Tea set \\
\hline & Toy soldiers \\
\hline & Tub toys \\
\hline & Vacuum cleaner \\
\hline & Workbench and tools \\
\hline
\end{tabular}


13. If your child were given each of the following toys, how likely is it that your child would play with the toy?

\begin{tabular}{|c|c|c|c|c|}
\hline $\mathbf{1}$ & $\mathbf{2}$ & $\mathbf{3}$ & $\mathbf{4}$ & $\mathbf{5}$ \\
\hline $\begin{array}{c}\text { Not at all likely } \\
\text { (Would never or } \\
\text { almost never } \\
\text { play with this } \\
\text { toy.) }\end{array}$ & $\begin{array}{c}\text { Somewhat } \\
\text { unlikely } \\
\text { (Variable, but } \\
\text { probably would } \\
\text { not play with this } \\
\text { toy.) }\end{array}$ & $\begin{array}{c}\text { Equal } \\
\text { (Equally likely } \\
\text { and unlikely to } \\
\text { play with this } \\
\text { toy.) }\end{array}$ & $\begin{array}{c}\text { Somewhat likely } \\
\text { (Variable, but } \\
\text { probably would } \\
\text { play with this } \\
\text { toy.) }\end{array}$ & $\begin{array}{c}\text { Extremely likely } \\
\text { (Would always or } \\
\text { almost always } \\
\text { play with this } \\
\text { toy.) }\end{array}$ \\
\hline
\end{tabular}

\begin{tabular}{|l|l|}
\hline & Audio cassettes \\
\hline & Baby doll \\
\hline & Baby feeding set \\
\hline & Barbecue grill \\
\hline & Barbie \\
\hline & Batman \\
\hline & Batmobile \\
\hline & Bracelets \\
\hline & Cabbage Patch doll \\
\hline & Camera \\
\hline & Carpentry tool set \\
\hline & Cassette player \\
\hline & Catwoman \\
\hline & Chalkboard \\
\hline & Chime ball \\
\hline & Construction truck \\
\hline & Cowboy \\
\hline & Cradle \\
\hline & Doctor kit \\
\hline & Doll house \\
\hline & Doll house furniture \\
\hline & Dress-up clothes \\
\hline & Easel \\
\hline & Educational books \\
\hline & \\
\hline
\end{tabular}

\begin{tabular}{|l|l|}
\hline & Esmerelda doll \\
\hline & Female superhero \\
\hline & Finger paints \\
\hline & Fireman hat \\
\hline & Firetruck \\
\hline & Football gear \\
\hline & Garage and cars \\
\hline & Gas station and cars \\
\hline & Gl Joe \\
\hline & Globe \\
\hline & Godzilla \\
\hline & Hand puppet \\
\hline & Jewelry box \\
\hline & Kaleidoscope \\
\hline & Kitchen center \\
\hline & Magna-Doodle \\
\hline & Magnetic letters \\
\hline & Male superhero \\
\hline & Matchbox cars \\
\hline & Mickey Mouse \\
\hline & Minnie Mouse \\
\hline & Miss Piggy \\
\hline & Motorcycle \\
\hline & Ninja Warrior Set \\
\hline & \\
\hline
\end{tabular}

\begin{tabular}{|l|l|}
\hline & Palace \\
\hline & Piano \\
\hline & Picture books \\
\hline & Play Dough Factory \\
\hline & Pocahontas doll \\
\hline & $\begin{array}{l}\text { Police helmet and } \\
\text { vest }\end{array}$ \\
\hline & Pots and pans \\
\hline & Power Rangers \\
\hline & Puzzles \\
\hline & Race car \\
\hline & Race track set \\
\hline & Ring toss \\
\hline & Rubber duck \\
\hline & Snap-together beads \\
\hline & Spiderman \\
\hline & Stacking rings \\
\hline & Stroller \\
\hline & Tea set \\
\hline & Toy soldiers \\
\hline & Tub toys \\
\hline & Vacuum cleaner \\
\hline & Workbench and tools \\
\hline
\end{tabular}


14. How likely would your child be to protest if each of the following toys were taken away while he or she was playing with them?

\begin{tabular}{|c|c|c|c|c|}
\hline $\mathbf{1}$ & $\mathbf{2}$ & $\mathbf{3}$ & $\mathbf{4}$ & $\mathbf{5}$ \\
\hline $\begin{array}{c}\text { Not at all likely } \\
\text { (Would never or } \\
\text { almost never } \\
\text { protest.) }\end{array}$ & $\begin{array}{c}\text { Somewhat } \\
\text { unlikely } \\
\text { (Variable, but } \\
\text { probably would } \\
\text { not protest.) }\end{array}$ & $\begin{array}{c}\text { Equal } \\
\text { (Equally likely } \\
\text { and unlikely to } \\
\text { protest.) }\end{array}$ & $\begin{array}{c}\text { Somewhat } \\
\text { likely } \\
\text { (Variable, but } \\
\text { probably } \\
\text { would protest.) }\end{array}$ & $\begin{array}{c}\text { Extremely likely } \\
\text { (Would always } \\
\text { or almost always } \\
\text { protest.) }\end{array}$ \\
\hline
\end{tabular}

\begin{tabular}{|l|l|}
\hline & Audio cassettes \\
\hline & Baby doll \\
\hline & Baby feeding set \\
\hline & Barbecue grill \\
\hline & Barbie \\
\hline & Batman \\
\hline & Batmobile \\
\hline & Bracelets \\
\hline & Cabbage Patch doll \\
\hline & Camera \\
\hline & Carpentry tool set \\
\hline & Cassette player \\
\hline & Catwoman \\
\hline & Chalkboard \\
\hline & Chime ball \\
\hline & Construction truck \\
\hline & Cowboy \\
\hline & Cradle \\
\hline & Doctor kit \\
\hline & Doll house \\
\hline & Doll house furniture \\
\hline & Dress-up clothes \\
\hline & Easel \\
\hline & Educational books \\
\hline & \\
\hline
\end{tabular}

\begin{tabular}{|l|l|}
\hline & Esmerelda doll \\
\hline & Female superhero \\
\hline & Finger paints \\
\hline & Fireman hat \\
\hline & Firetruck \\
\hline & Football gear \\
\hline & Garage and cars \\
\hline & Gas station and cars \\
\hline & Gl Joe \\
\hline & Globe \\
\hline & Godzilla \\
\hline & Hand puppet \\
\hline & Jewelry box \\
\hline & Kaleidoscope \\
\hline & Kitchen center \\
\hline & Magna-Doodle \\
\hline & Magnetic letters \\
\hline & Male superhero \\
\hline & Matchbox cars \\
\hline & Mickey Mouse \\
\hline & Minnie Mouse \\
\hline & Miss Piggy \\
\hline & Motorcycle \\
\hline & Ninja Warrior Set \\
\hline & \\
\hline
\end{tabular}

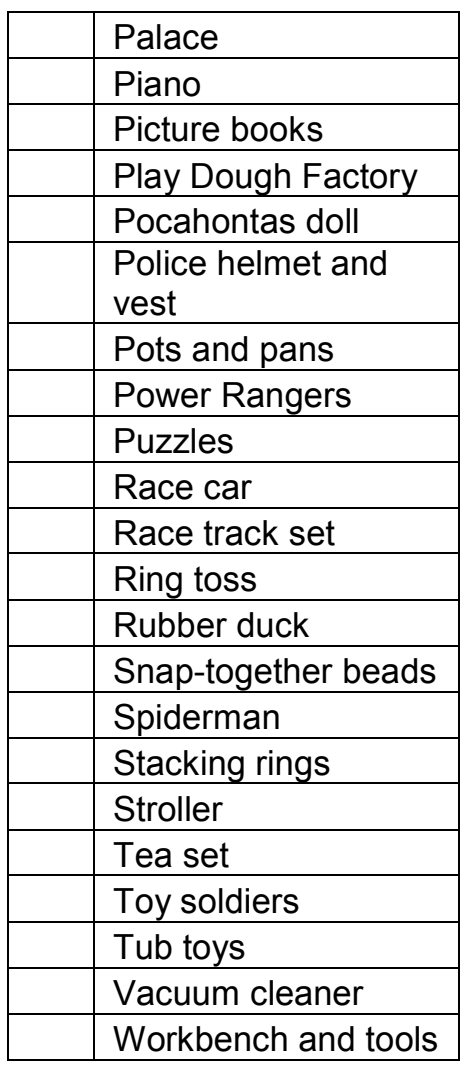




\section{Appendix G}

\section{Adult Personality Inventory}

Please rate yourself on each of the following items using the following scale:

\begin{tabular}{|c|c|c|c|c|c|c|}
\hline 1 & 2 & 3 & 4 & 5 & 6 & 7 \\
\hline $\begin{array}{c}\text { Never or } \\
\text { almost } \\
\text { never true }\end{array}$ & $\begin{array}{c}\text { Usually } \\
\text { not true }\end{array}$ & $\begin{array}{c}\text { Sometimes } \\
\text { but } \\
\text { infrequentl } \\
\text { true }\end{array}$ & $\begin{array}{c}\text { Occasionally } \\
\text { true }\end{array}$ & $\begin{array}{c}\text { Often } \\
\text { true }\end{array}$ & $\begin{array}{c}\text { Usually } \\
\text { true }\end{array}$ & $\begin{array}{c}\text { Always or } \\
\text { almost } \\
\text { always true }\end{array}$ \\
\hline
\end{tabular}

1. Self-reliant

2. Yielding

3. Helpful

4. Defends own beliefs

5. Cheerful

6. Moody

7. Independent

8. Shy

9. Conscientious

10. Athletic

11. Affectionate

12. Theatrical

13. Assertive

14. Flatterable

15. Happy

16. Strong Personality

17. Loyal

18. Unpredictable

19. Forceful

20. Feminine

21. Reliable

22. Analytical

23. Sympathetic

24. Jealous

25. Leadership ability

26. Sensitive to other's needs

27. Truthful

28. Willing to take risks

29. Understanding

30. Secretive
31. Makes decisions easily

32. Compassionate

33. Sincere

34. Self-sufficient

35. Eager to soothe hurt feelings

36. Conceited

37. Dominant

38. Soft-spoken

39. Likable

40. Masculine

41. Warm

42. Solemn

43. Willing to take a stand

44. Tender

45. Friendly

46. Aggressive

47. Gullible

48. Inefficient

49. Acts as a leader

50. Childlike

51. Adaptable

52. Individualistic

53. Does not use harsh language

54. Unsystematic

55. Competitive

56. Loves children

57. Tactful

58. Ambitious

59. Gentle

60. Conventional 


\section{Appendix $\mathrm{H}$}

\section{Background Information}

1. Today's Date:

2. Please list the first names of the adults, excluding yourself, living in the household and their relation to the child.

First Name

Relation to child

Please answer questions 3 - 13 with regards to yourself and the child's other guardian. If only one parent is participating, please answer all questions. If both parents are participating, questions $3-13$ need only be answered by one parent.

3. Age of self:

4. Sex of self: $\quad$ Male $\quad$ Female

5. Current occupation for self:

6. Age of other parent/guardian:

7. Sex of other parent/guardian: Male Female

8. Current occupation for other parent/guardian:

9. Highest level of education completed for self:
A. Less than high school
B. High school graduate
C. Some college
D. College graduate
E. Some graduate or professional school
F. Completed graduate or professional school 
10. Highest level of education completed for other parent/guardian:
A. Less than high school
B. High school graduate
C. Some college
D. College graduate
E. Some graduate or professional school
F. Completed graduate or professional school

11. Ethnic background of self:
A. African American
B. Asian/Pacific Islander
C. Hispanic
D. Non-Hispanic Caucasian
E. Native American
F. Other

12. Ethnic background of other parent/guardian:
A. African American
B. Asian/Pacific Islander
C. Hispanic
D. Non-Hispanic Caucasian
E. Native American
F. Other

13. Marital Status:
A. Married
B. Divorced
C. Separated
D. Single, never married
E. Cohabitating

If married, how long have you been married?

14. Child's sex: Male Female

15. Child's birthdate: Month Day___ Year

16. How much time do you spend playing with your child during a normal day? 
17. Does your child attend daycare or receive child care? Yes No If yes, for how long each day?

How many of the other children in daycare are girls?

How many of the other children in daycare are boys?

18. Outside of daycare or childcare, how many other children does your child play with on a regular basis?

How many are girls?

How many are boys?

19. How many siblings does your child have?

How many sisters?

Age(s):

How many brothers?

Age(s):

20. Do you plan to have more children some day?
A. Yes
B. No
C. Not sure 